\title{
Artistic Liberty and Slave Imagery: "Mark Twain's Illustrator," E. W. Kemble, Turns to Harriet Beecher Stowe
}

Adam Sonstegard

Cleveland State University, a.sonstegard@csuohio.edu

Follow this and additional works at: https://engagedscholarship.csuohio.edu/cleng_facpub

Part of the American Literature Commons, American Popular Culture Commons, Illustration

Commons, and the Literature in English, North America Commons

How does access to this work benefit you? Let us know!

Publisher's Statement

University of California Press. This article first appeared in Nineteenth-Century Literature, Volume 63, Issue 4, March 2009, 499-542. http://www.jstor.org/stable/10.1525/ ncl.2009.63.4.499

\section{Original Published Citation}

Sonstegard, Adam. "Artistic Liberty and Slave Imagery: 'Mark Twain's Illustrator," E. W. Kemble, Turns to Harriet Beecher Stowe." Nineteenth-Century Literature, vol. 63, no. 4, 2009, pp. 499-542. www.jstor.org/ stable/10.1525/ncl.2009.63.4.499.

This Article is brought to you for free and open access by the English Department at EngagedScholarship@CSU. It has been accepted for inclusion in English Faculty Publications by an authorized administrator of EngagedScholarship@CSU. For more information, please contact library.es@csuohio.edu. 
Artistic Liberty and Slave Imagery: "Mark Twain's Illustrator," E. W. Kemble, Turns to Harriet Beecher Stowe

Author(s): Adam Sonstegard

Source: Nineteenth-Century Literature, Vol. 63, No. 4 (March 2009), pp. 499-542

Published by: University of California Press

Stable URL: http://www.jstor.org/stable/10.1525/ncl.2009.63.4.499

Accessed: 10-03-2017 16:27 UTC

JSTOR is a not-for-profit service that helps scholars, researchers, and students discover, use, and build upon a wide range of content in a trusted

digital archive. We use information technology and tools to increase productivity and facilitate new forms of scholarship. For more information about JSTOR, please contact support@jstor.org.

Your use of the JSTOR archive indicates your acceptance of the Terms \& Conditions of Use, available at

http://about.jstor.org/terms

University of California Press is collaborating with JSTOR to digitize, preserve and extend access to Nineteenth-Century Literature 


\title{
Artistic Liberty and Slave Imagery: "Mark Twain's Illustrator,” E. W. Kemble, Turns to Harriet Beecher Stowe
}

\author{
ADAM SONSTEGARD
}

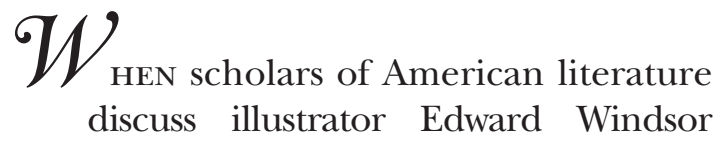

Kemble (1861-1933), their conversations have a curious way of beginning and ending with Mark Twain. According to these conversations, the author in his late forties contacted an artist in his early twenties and gave him the opportunity to illustrate Adventures of Huckleberry Finn (1884-85). The author originally found the artist's images "generally ugly" and "forbidding and repulsive," then decided that a latter group of them was "most rattling good," but eventually wrote that, if he had to make the choice over again, he would note the "tiresome" "sameness" of the artist's images, and "would promptly put them into the fire." These conversations

Nineteenth-Century Literature, Vol. 63, No. 4, pp. 499-542. ISSN: o891-9356, online ISSN: 10678352. (C) 2009 by The Regents of the University of California. All rights reserved. Please direct all requests for permission to photocopy or reproduce article content through the University of California Press's Rights and Permissions website, at http://www.ucpress.edu/journals/ rights.htm.

${ }^{1}$ Mark Twain, letters to Charles L. Webster, 24 May 1884 and 11 June 1884 , in Mark Twain, Business Man, ed. Samuel Charles Webster (Boston: Little, Brown and Co., 1946), pp. 255, 260. Twain later objected to the images that Kemble produced for Mark Twain's Library of Humor (1888), remarking: "If Kemble illustrations for my last book were handed me today, I could understand how tiresome to me that sameness would get to be, 
often turn to Kemble, and note how the artist had the same model, a Caucasian lad named Cort Morris, pose for Huck, Jim, and every other character in Twain's novel; how Kemble earned a reputation for rendering African Americans as his "specialty"; and how he won acclaim for depicting Twain's Southwestern humor, though Kemble claimed that he had not been farther south than New York City. ${ }^{2}$ Older versions of these conversations praise Kemble as a "master of his craft." Subsequent versions stridently criticize him for reactionary, stereotypical illustrations, for seeming to compromise the progressive politics of Huckleberry Finn, and even for casting doubt on Twain's intentions, in light of his decision to have the novel feature Kemble's illustrations. ${ }^{3}$

Kemble's work crosses surprising nineteenth-century demographic and ideological lines, and ranges more broadly than one would realize from these conversations on Kemble and Twain. Though cartoons from Kemble often amounted to cruel caricatures of African Americans, he also offered painstaking, almost sociological studies of black culture for George Washington Cable's Century article on bamboula dancing in New Orleans's Congo Square (see Figure 1). Though Kemble lent

when distributed through a whole book, and I would put them promptly into the fire" (Mark Twain, quoted from July 1889, in Mark Twain's Letters to His Publishers, I 867-I 894, ed. Hamlin Hill [Berkeley and Los Angeles: Univ. of California Press, 1967], p. 254n). My thanks to Beth Lueck, Cindy Weinstein, Ryan Cordell, Tess Chakkalakal, and Ellen Joy Letostek of the Harriet Beecher Stowe Society; to Jeff Karem, Rachel Carnell, James Marino, Gary Dyer, and Leonard Spacek of Cleveland State University; and to Stephen F. Railton for his suggestions and assistance as a reader-reviewer.

${ }^{2}$ See Edward Windsor Kemble, "Illustrating Huckleberry Finn," The Colophon, A Book Collector's Quarterly, February 1930 (available online at <http://etext.virginia.edu/railton/ huckfinn/colophon.html >). Kemble writes in this article that, when he began to draw for Century Magazine, he had "never been further south than Sandy Hook," New Jersey. Native to Sacramento, California, Kemble did eventually travel to New Orleans in 1885 and to rural Georgia in 1891, in order to observe subjects for his Century Magazine illustrations.

${ }^{3}$ Critical responses to Kemble's collaboration with Twain include Beverly R. David, "The Pictorial Huck Finn: Mark Twain and His Illustrator, E. W. Kemble," American Quarterly, 26 (1974), 331-51; and Beverly R. David, "Visions of the South: Joel Chandler Harris and His Illustrators," American Literary Realism, 9 (1976), 189-206; Francis Martin, Jr., "Edward Windsor Kemble, a Master of Pen and Ink," American Art Review, 3, no. 1 (1976), 54-67; Earl F. Briden, "Kemble's 'Specialty' and the Pictorial Countertext of Huckleberry Finn," Mark Twain Journal, 26, no. 2 (1988), 2-14; Douglas Anderson, "Reading the Pictures in Huckleberry Finn," Arizona Quarterly, 42 (1986), 101-20; and Kelly Anspaugh, "The Innocent Eye? E. W. Kemble's Illustrations to Adventures of Huckleberry Finn," American Literary Realism, 25, no. 2 (1993), 16-30. 


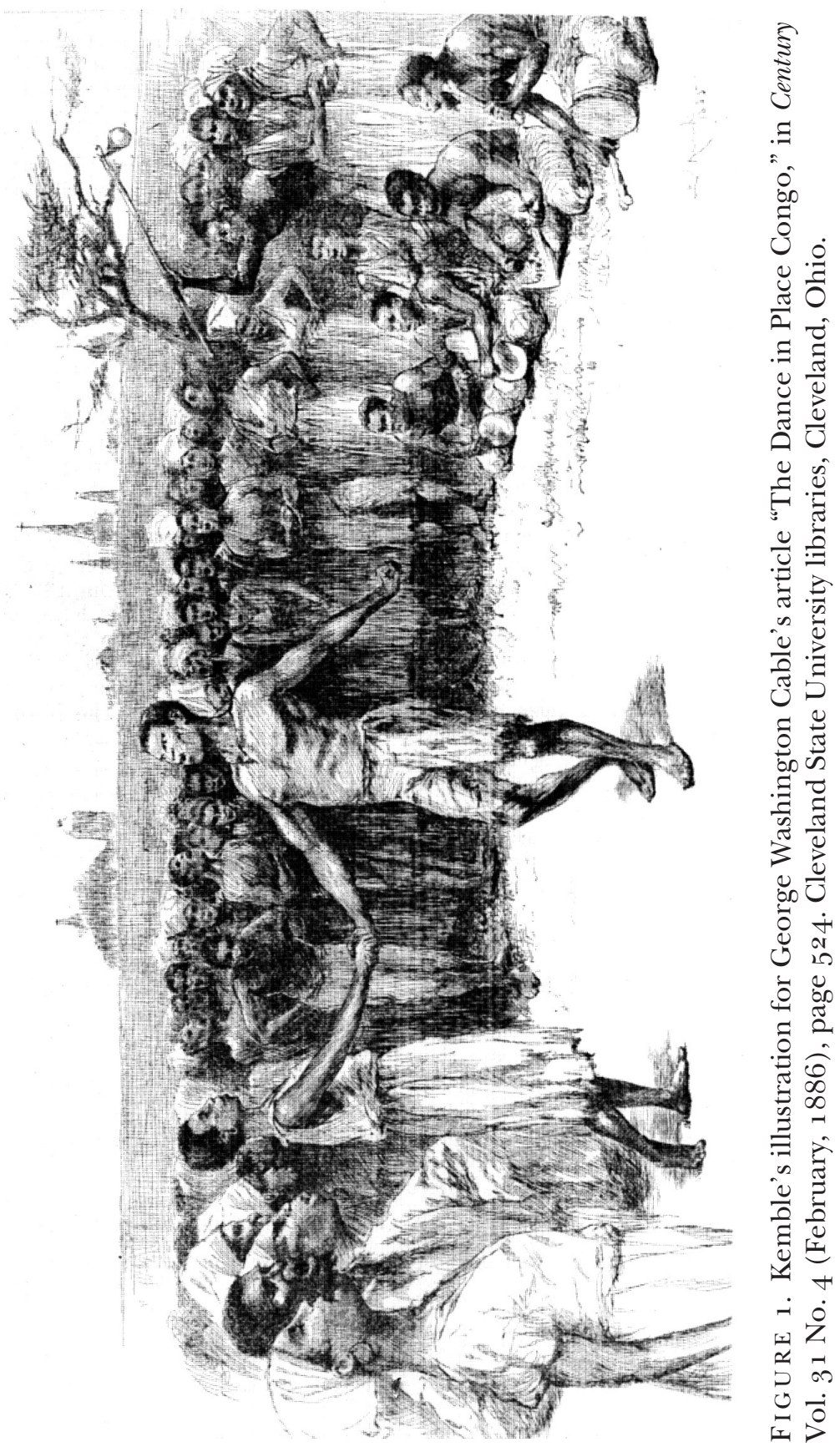


a visual dimension to the Southern plantation fiction of such writers as Joel Chandler Harris and Thomas Nelson Page, his work also adorned the pages of reissued classics with decidedly Northern or New England perspectives, such as an 1891 edition of Harriet Beecher Stowe's Uncle Tom's Cabin (1852) and an 1894 edition of Washington Irving's Knickerbocker's History of New York (1809). Though Kemble authored such virulently racist books as Coontown's 400 (1899) and Kemble's Pickaninnies: A Collection of Southern Sketches (1901), he also supplied illustrations for short stories by the folklorist Joel Chandler Harris and the African American writer Paul Laurence Dunbar. The fictions that Kemble illustrates that are set in the American South delight in racist caricatures, yet when he "is depicting slavery somewhere else," some location where "American whites need feel no responsibility for it," Stephen Railton writes, Kemble "draws slaves with human faces instead of blackface minstrel masks, and depicts their human suffering realistically." quiry to Kemble's association with Twain oversimplifies this visual artist's complicated career of intricately, inconsistently constructing and representing varied American racial, ethnic, and socioeconomic groups. Writing Kemble off as egregiously racist makes it difficult to explain his subsequent commissions to illustrate Stowe's, Harris's, and Dunbar's African American subject matter.

\footnotetext{
${ }^{4}$ Stephen Railton, Mark Twain in His Times, Univ. of Virginia Libraries and Electronic Text Center, available online at <http://etext.virginia.edu/railton/index2. html>. Mark Twain in His Times, the most thorough exploration of Kemble's and Twain's careers in depicting race and slavery in late-nineteenth-century American culture, anticipates my own argument in explaining, "From $188_{5}$ through the first couple decades of the 2oth century, white America loved [Kemble's] usually clownish and always stereotypical representations of blacks," representations that made light of contemporary racial politics and that excused those white audiences from having to take any responsibility for the country's history of slavery (see "Kemble's Images of African Slavery," at <http://etext.virginia.edu/railton/wilson/slavery/mtslavhp.html >). Other explorations of Kemble's career beyond his work with Twain include: Martin, "Edward Windsor Kemble, a Master of Pen and Ink"; Elvin Holt, "A Coon Alphabet and the Comic Mask of Racial Prejudice," Studies in American Humor, 5 (1986), 207-18; Werner Sollors, "Was Roxy Black? Race as Stereotype in Mark Twain, Edward Windsor Kemble, and Paul Laurence Dunbar," in Mixed Race Literature, ed. Jonathan Brennan (Stanford: Stanford Univ. Press, 2002), pp. 70-87; and Henry B. Wonham, Playing the Races: Ethnic Caricature and American Literary Realism (New York: Oxford Univ. Press, 2004).
} 
Remembering Kemble solely as "Mark Twain's illustrator" also prevents researchers from recuperating the even more interesting racial politics of Kemble's efforts to illustrate and market the work of Harriet Beecher Stowe. ${ }^{5}$ While Adventures of Huckleberry Finn called for Kemble's antebellum scenes as nostalgic flights from the author's advancing middle age and from the country's corrupt, racially divisive Gilded Age, Uncle Tom's Cabin demanded that Kemble directly depict concurrent controversies - the Fugitive Slave Law, slaveowners' sadism, racial amalgamation. While Twain's storyline forces scholars to discern Twain's views on race from critical triangulation with his adolescent narrator, from collaboration with Kemble, and from depictions of Jim, Stowe's storyline offers Kemble the opportunity to render the racism and white privilege that he and Twain had avoided. Kemble's work with Twain is only the beginning of his history of illustrating interracial relationships in American literature; his work with Stowe is part of that history's culmination. Having asked questions about Kemble and Twain for decades, we have seldom turned for answers to Kemble and Stowe. ${ }^{6}$

A comparison of Kemble's illustrations for the two classic novels reveals that Kemble strategically broadens the appeal of liberal, progressive novels for more conservative, even reactionary audiences. He produces an Adventures of Huckleberry Finn calculated to reach Northern liberals as well as Southerners nostalgic for the days of Twain's boyhood. He illustrates an edition of Uncle Tom's Cabin marketed to reach those who also read Joel Chandler Harris, George Washington Cable, and Thomas Nelson Page. The same comparison demonstrates that Kemble follows an iconography that severely circumscribes representations

\footnotetext{
${ }^{5}$ See David, "The Pictorial Huck Finn: Mark Twain and His Illustrator, E. W. Kemble."

${ }^{6}$ Criticism that touches upon Kemble's illustrations for Stowe include Wonham, Playing the Races; Julia Thomas, Pictorial Victorians: The Inscription of Values in Word and Image (Athens: Ohio Univ. Press, 2004); Paul C. Gutjahr, "Pictures of Slavery in the United States: Consumerism, Illustration, and the Visualization of Stowe's Novel," in Approaches to Teaching Stowe's "Uncle Tom's Cabin," ed. Elizabeth Ammons and Susan Belasco (New York: Modern Language Association, 2000), pp. 77-92; and Werner Sollors, "Was Roxy Black? Race as Stereotype in Mark Twain, Edward Windsor Kemble, and Paul Laurence Dunbar."
} 
of interracial relationships. His visual images favor the King and the Duke's antics, but skirt some of Huck and Jim's most intimate moments. His renderings of Uncle Tom and Little Eva similarly obscure the striking intimacy of the prose passages that narrate their relationship. The comparison dramatizes how Kemble works as an ancillary author as well as an advance reader working from within popular-culture audiences. He renders Jim in antebellum days, as Twain's reconstructs him verbally-but only as Gilded Age Americans were willing to perceive him visually. He renders Uncle Tom, as Stowe describes him verbally in the $185^{\mathrm{os}}$-but only as the iconographic "Uncle Tom," as Americans were willing to recognize his image in the 1890 s. Visually complementing the authors' verbal art, Kemble anticipates the revisionist tendencies of receptive reading audiences.

The comparison shows that Kemble could render enslaved African Americans or impoverished European Americans as delineated individuals or as stereotypical figures, as he caters to audiences that had a stake in seeing these characters as unique personalities or as racialized "types." Marketing Twain's and Stowe's novels for mass audiences, Kemble mediates between literary authors who invest marginalized characters with distinct personalities and empowered, mainstream audiences who were less willing to accept individuality in minority figures. Kemble was not the egregiously racist exception for his time, but a reliable rule for the mainstream American publishing establishment; he typified Gilded Age readers who enjoyed the privileges of purchasing, reading, and illustrating literary representations of marginalized subjects—subjects who clearly did not enjoy such social privileges themselves. ${ }^{7}$ When Kemble

${ }^{7}$ I am not making the claim that Kemble was somehow above the commonly held racial, ethnic, and socioeconomic prejudices of his time, or that he should be recognized as a sensitive, multicultural artist for our time. I argue, rather, that the prevalence of his work from the 188 os through the 1910 s, and the record of his having collaborated with writers ranging from Stowe to Twain to Harris to Dunbar to Page, indicate that mainstream Americans found Kemble's work to be acceptable renditions of socially disadvantaged and minority American groups. The discussion that follows cannot encompass all of the $14^{6}$ images that Kemble contributes to this edition of Uncle Tom's Cabin, and instead highlights images that compare with Kemble's illustrations for Adventures of Huckleberry Finn. 
takes artistic liberties in illustrating literary representations of slavery, so to speak, he demonstrates graphically how Gilded Age readers were taking their own liberties reinterpreting these stories of slaves.

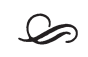

Both Adventures of Huckleberry Finn and Uncle Tom's Cabin invite readers and illustrators to pretend that they are directly seeing, not merely reading about, the narratives' fictional settings. Twain invites readers to imagine that they glimpse the Mississippi Valley countryside from an adolescent's untutored point of view, while Stowe invites her readers to take a fresh look at slavery-a subject that they thought they had known so well. A detailed account of Haley's appearance in the first paragraph of Uncle Tom's Cabin gives way to a vivid description of dancing Jim Crow. "Doubt not that it is [Aunt Chloe] you see by the fire," "viewers" are told, and "Miss Ophelia, as you now behold her, stands before you." "As he is to be the hero of our story," Stowe writes as she first introduces Uncle Tom, "we must daguerreotype him for our readers. He was a large, broad-chested, powerfully-made man, of a full glossy black" (Uncle Tom's Cabin, p. 26). Stowe appropriates the surface glossiness and formal framing of visual media for descriptive prose. In presenting a sympathetic character she pretends to "daguerreotype" Uncle Tom, and in introducing an unsympathetic one she has Marie St Clair disregard a daguerreotype. As the negligent mother yawns over her family's studio portrait, readers have one more reason to dislike Marie.

As for the least likeable character, Simon Legree, the novel introduces the sadistic plantation-owner in language that is both disturbing and photographic: Legree's "round, bullet head,"

${ }^{8}$ Harriet Beecher Stowe, Uncle Tom's Cabin, or, Life Among the Lowly, ed. Kenneth S. Lynn (Cambridge, Mass.: Belknap Press of Harvard Univ. Press, 1962), pp. 24, 164 . Further references to Uncle Tom's Cabin are from this edition and appear parenthetically in the text. Images are drawn from Harriet Beecher Stowe, Uncle Tom's Cabin, or Life Among the Lowly, with illustrations by E. W. Kemble (New York: Riverside Press, 1891), courtesy Clifton Waller Barrett Library of American Literature, Special Collections, University of Virginia Library. 
"shaggy, sandy eye-brows," "sun-burned hair," and "large, coarse mouth . . . distended with tobacco" seem calculated in their repulsiveness; "his hands were immensely large, hairy, sun-burned, freckled, and very dirty, and garnished with long nails, in a very foul condition" (Uncle Tom's Cabin, p. 341). Stowe reverses the slavemaster's gaze: as Legree appraises Tom according to his appearances and judges Tom's capacities as laboring chattel, Stowe appraises Legree according to his appearances and sizes him up for his capacities as abolitionist rhetoric. Stowe empowers readers to respond sympathetically to scenes that they imagine they glimpse for themselves. She encourages them to reject the point of view of slaveowners like Legree. She turns an objectifying, commodifying gaze back onto grotesque slaveowning interests.

The novel also included visual components, both in its serialized appearances in periodicals and in its initial publications as a book. The 19 June $185^{1}$ issue of National Era, which carried the installment of Uncle Tom's Cabin in which Stowe claimed "we must daguerreotype" Uncle Tom, also carried an advertisement for a daguerreotypist. Readers of the issue could take in Stowe's portrait-based novel, and also contemplate sitting for their own portraits. The 4 March $185^{2}$ issue announced that Jewett and company would have the novel ready in book form by 20 March, including "six elegant illustrations by [Hammatt] Billings." ${ }^{9}$ Even before the periodical carried the novel's closing episodes, visual images of its famous moments had begun to appear. Hammatt Billings, a New England illustrator and architect, supplied seven illustrations for the novel's first hardcover edition, and 117 new illustrations for a supplemented edition that John Jewett published in $185^{2}$. Houghton Mifflin had published new illustrated editions by the $1880 \mathrm{os}$, as well as a Christmas edition for 1891 with Kemble's illustrations. ${ }^{10}$ Paul C. Gutjahr cautions: “After Jewett's

${ }^{9}$ This information is drawn and quoted from the edition of Uncle Tom's Cabin comprised of National Era issues, $185^{1-1} 85^{2}$, at the Small Library Special Collections, University of Virginia: Mrs. H. B. Stowe, Uncle Tom's Cabin, or Life Among the Lowly, (Washington, D.C.: National Era, 5 June $185^{1-1}$ April 1852), courtesy Clifton Waller Barrett Library of American Literature, Harriet Beecher Stowe Collection. Special Collections, University of Virginia Library Libraries, Charlottesville, Va.

${ }^{10}$ For information on illustrators of Uncle Tom's Cabin who preceded Kemble, including Billings and George Cruikshank, see Marcus Wood, Blind Memory: Visual 
first edition of Uncle Tom's Cabin, the novel was never a single, uniform entity," thanks to the "different bindings, type fonts, paper, introductions, illustrations, and even subtitles" ("Pictures of Slavery in the United States," p. 78). Nor was it ever a purely verbal phenomenon: it invited readers to imagine that they were seeing slavery firsthand, as it licensed illustrators to lend added dimensions to Stowe's visual rhetoric.

Uncle Tom's Cabin even licensed visual artists to help Stowe define her literary endeavor. The novel's various illustrators, as Julia Thomas observes, could emphasize the portions of the novel to which readers should pay particular attention. "By selecting certain incidents at the expense of others and pasting these together," Thomas writes, "illustration can construct its own relations, even its own narrative," and encourage readers to remember, or allow readers to forget, images the artists select for illustration (Pictorial Victorians, p. 32). Michael T. Gilmore is right in one respect, then, in observing that only one paragraph describes Eliza's famous flight across the Ohio River. ${ }^{11}$ Illustrators repeatedly selected that scene, making it an indelible image and lending it the quality of an animated film unfolding before viewers, rather than a single paragraph on the page. Illustrators had the symbolic power to look at the text as if with microscopes, expand minutiae into full-page images, and settle such questions as characters' skin tone in supposedly authoritative images. Kemble's choices in this famous scene, for instance, reflect his awareness of earlier renderings, the tendency to draw Harry to look very girlish, and a penchant for an apparently Caucasian Eliza (see Figure 2). Stowe's rhetoric lends visual artists like Kemble a degree of authorship in emphasizing and visually interpreting her verbal work.

Representations of Slavery in England and America, I $780-1865$ (Manchester: Manchester Univ. Press, 2000); James F. O'Gorman, Accomplished in All Departments of Art: Hammatt Billings of Boston, I $8_{I} 8-I 874$ (Amherst: Univ. of Massachusetts Press, 1998); Thomas, Pictorial Victorians: The Inscription of Values in Word and Image; Paul C. Gutjahr, "Pictures of Slavery in the United States: Consumerism, Illustration, and the Visualization of Stowe's Novel"; and Jo-Ann Morgan, "Picturing Uncle Tom with Little Eva-Reproduction as Legacy," Journal of American Culture, 27 (2004), 1-24.

${ }^{11}$ Michael T. Gilmore, "Uncle Tom's Cabin and the American Renaissance: The Sacramental Aesthetic of Harriet Beecher Stowe," in The Cambridge Companion to Harriet Beecher Stowe, ed. Cindy Weinstein (Cambridge: Cambridge Univ. Press, 2004), p. 62. 


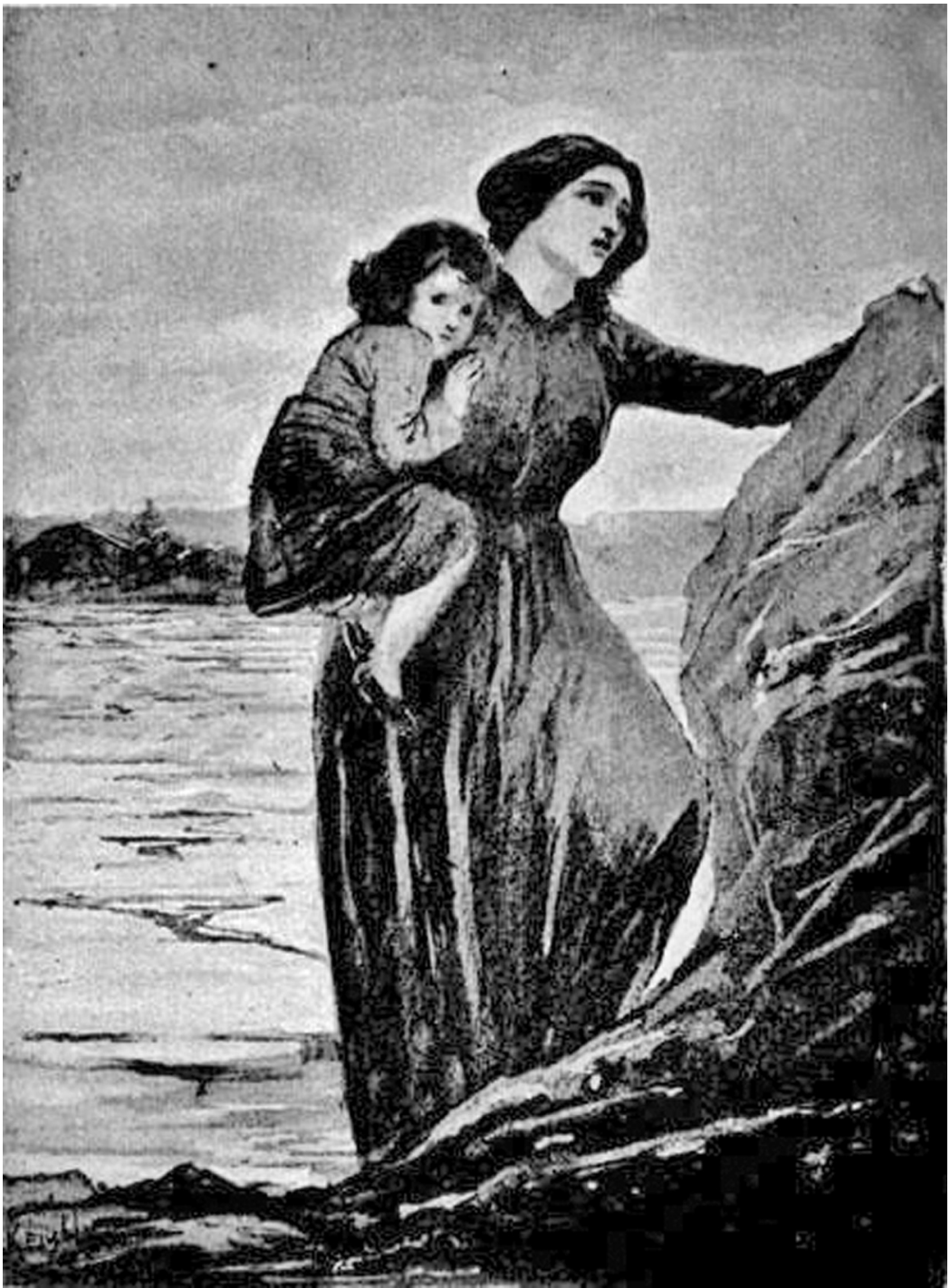

FIGURE 2. Kemble's image in 1892 for Eliza's famous crossing of the Ohio River in Uncle Tom's Cabin. Stowe, Harriet Beecher, Uncle Tom's Cabin, or Life Among the Lowly. With illustrations by E. W. Kemble. New York: Riverside Press, 1891. Courtesy, Clifton Waller Barrett Library of American Literature, Special Collections, University of Virginia Library. 
For the 1891 edition of Uncle Tom's Cabin, Kemble contributed $14^{6}$ total illustrations, including fourteen photogravures. Ten pages rarely pass in the two 3oo-page volumes without a Kemble illustration. The editors often match Kemble's imagery exactingly to Stowe's prose passages. Readers are told, for instance, that Stowe is giving an accurate description of Eliza, "not a fancy sketch" (Uncle Tom's Cabin, p. 15) less than an inch from an actual sketch. Images accompany descriptions of the same items, and a design element that a later era would call "textwrap" makes them coincide. "This is to be in every respect an entirely new edition of 'Uncle Tom's Cabin,'” Literary World's Publishing Announcements explained in September 1891, one "designed to be the best and most adequate presentation that has yet been made of this world-famous book." ${ }^{12}$ Houghton Mifflin marketed it as a "New Holiday edition" for Christmas, 1891, and sold its two volumes, "attractively bound," for four dollars. Kemble's illustrations are just as prominent and abundant in this new edition of Stowe's novel as his work had been in the first edition of Huckleberry Finn.

In Adventures of Huckleberry Finn Kemble had provided a frontispiece drawing attention to Twain's title character, but his frontispiece-photogravure for Uncle Tom's Cabin omits the title character, instead depicting the cabin (see Figure 3). Kemble adds a new image to what was already a familiar novel, and ushers in the relatively new art form of the etched photogravure, held to be a finer art than the more commonplace illustration. In the frontispiece a cabin stands off in the distance, separated from the reader by a fence, as if blocked off from realms to which the reader has access. A smiling cherub leans over the fence and toward the reader, as if serving as an ambassador to this territory. This introductory image suggests that readers will not be transported directly into the spaces of slavery's squalid horrors, but instead will encounter slavery viewed from a distance, cordoned off with fences, mediated by smiling guides. As it follows a portrait of Stowe, this image already gives evidence of artistic liberties: Stowe's chapter neither mentions any cabin nor offers readers such a guiding character.

\footnotetext{
12 "Publisher's Announcements," Literary World, A Monthly Review of Current Literature, 22 (1891), $33^{6 .}$
} 


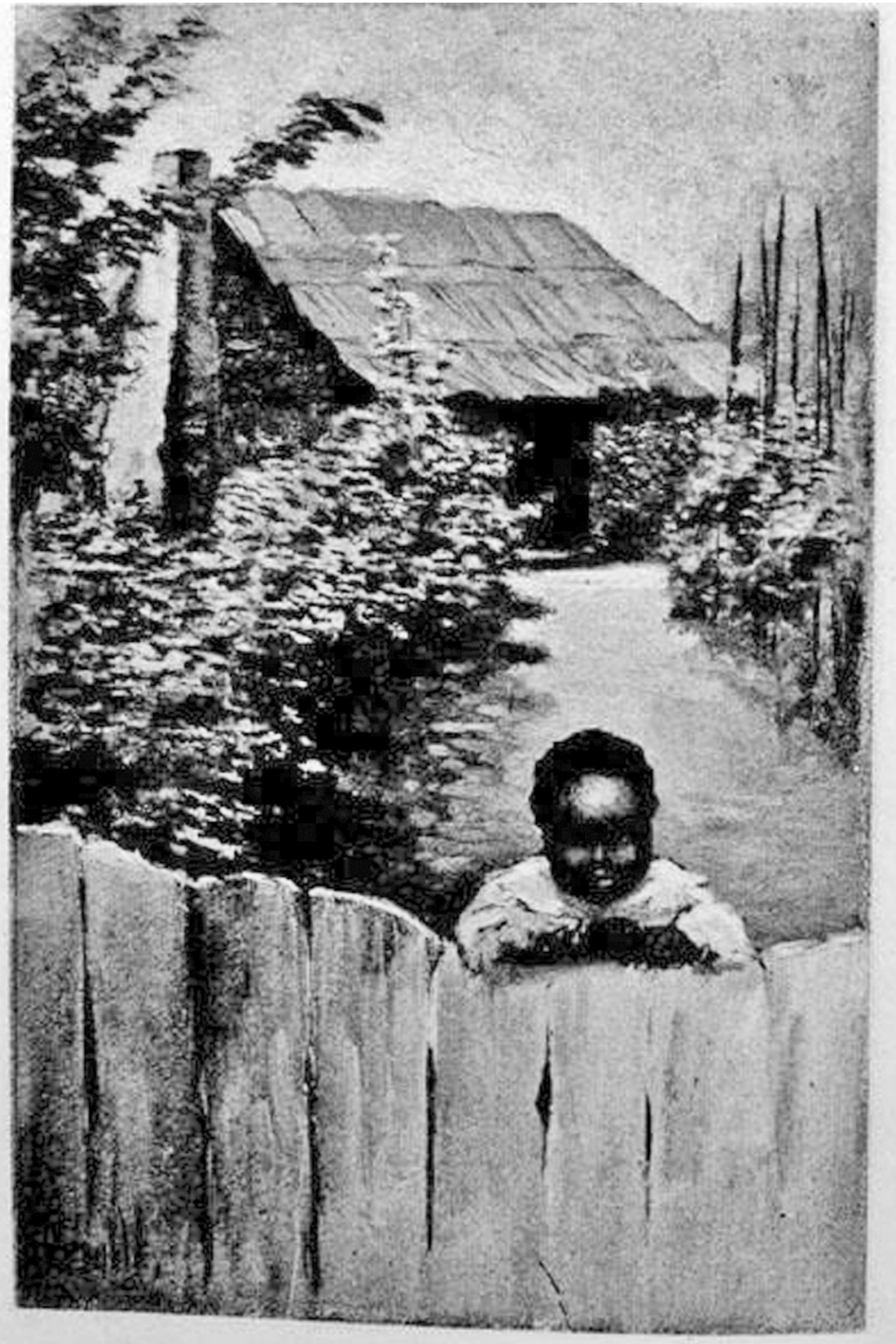

F I G URE 3. Kemble's introductory image to Chapter 1 of Uncle Tom's Cabin. Stowe, Harriet Beecher, Uncle Tom's Cabin, or Life Among the Lowly. With illustrations by E. W. Kemble. New York: Riverside Press, 1891. Courtesy, Clifton Waller Barrett Library of American Literature, Special Collections, University of Virginia Library. 
Kemble not only takes his liberties envisioning Uncle Tom's cabin (the structure itself), but also in representing Stowe's iconographic title character. Readers first meet Tom beneath "a portrait of General Washington, drawn and colored in a manner which would certainly have astonished that hero" (Uncle Tom's Cabin, p. 25). A second photogravure from Kemble even recalls Washington, as it depicts Uncle Tom complete with the suggestion of a colonial-era powdered wig (see Figure 4 ). The image enshrines Tom commemoratively, making him more of a revered icon, conventionally posed, and less of a live character, animated in the novel. The figure meets the viewer's glance, bears something akin to a knowing smirk, and seems cognizant of the viewer's knowledge of Tom's history. Kemble's pen-and-inks for Twain had graphically introduced characters whom readers were initially encountering, but Kemble's photogravure for Stowe relies upon readers' existing knowledge of Tom. Kemble does not introduce this already enshrined, commemorated rendition of Tom so much as imply that, in 1891 , he needs no introduction.

This image comes halfway through the second volume, long after Kemble passes up opportunities to depict Uncle Tom in a more vivacious pose. The chapter first introducing Tom contains a photogravure of Aunt Chloe, but none of Tom himself. Chapter 10 is adorned with a baby with a wide grin, but nothing in the image tells us what the chapter tells us-that Uncle Tom is holding the baby at the time. In a rendering for another chapter, a thirty-year-old slave named John looks off toward his left, rests his hand on the knee of someone who sits next to him, and addresses that person. The chapter makes it clear that John addresses Uncle Tom, though the image omits Tom as John's audience. Tom does not occupy the foreground of these images, as one might expect from a title character. Instead, he haunts the edition from just outside Kemble's picture frames.

When Kemble turns to Tom's interactions with Eva, this pattern of omissions continues. Readers of Kemble's edition have two images to depict all of Tom's interactions with Eva, and these images bracket their relationship, without visualizing any ongoing intimacy between them. One image shows Tom rescuing Eva after her plunge into the river, as water obscures most of Tom's and Eva's bodies (see Figure 5). Muddy 


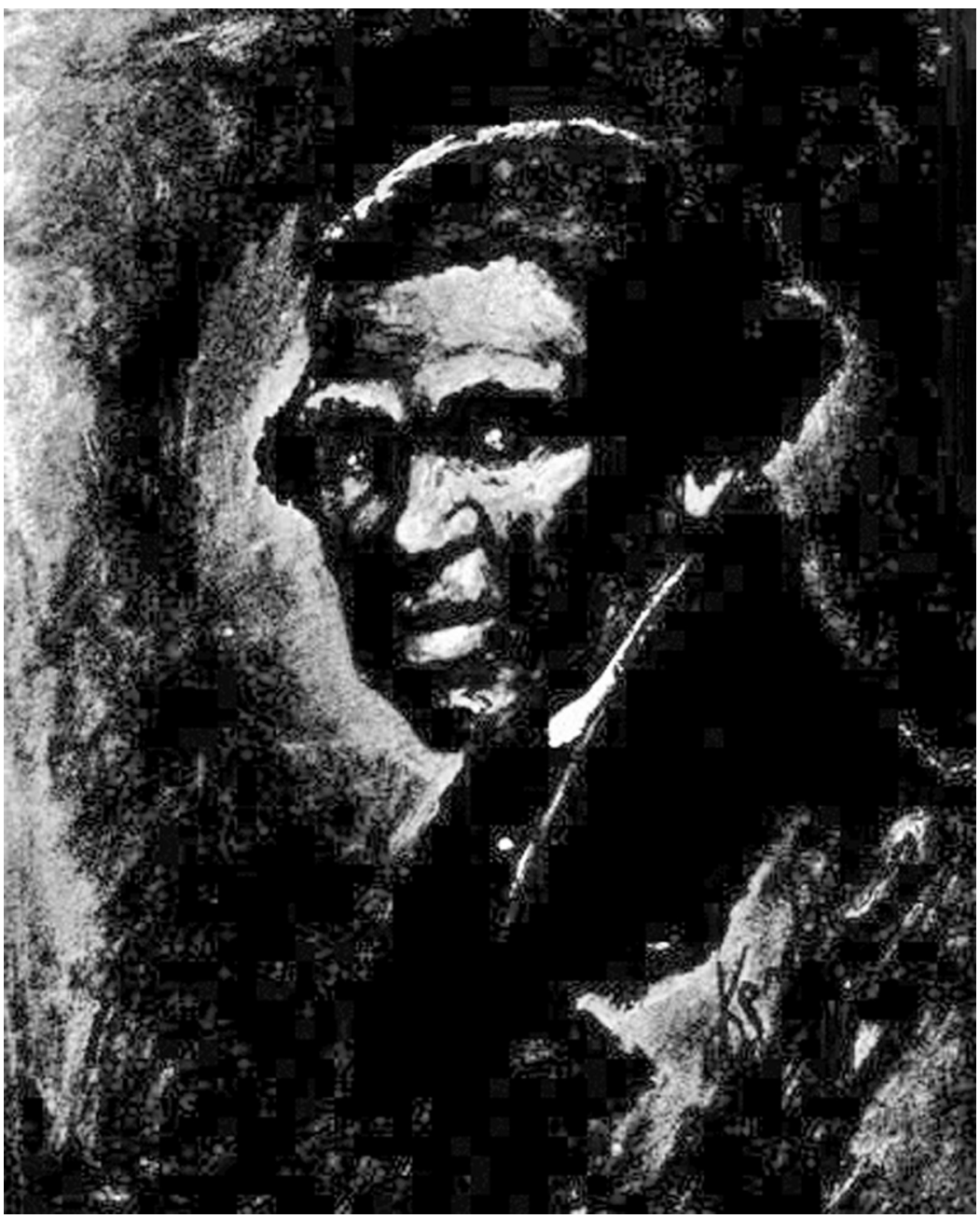

FIG URE 4. Kemble's “presidential” photogravure of Stowe's title character. Stowe, Harriet Beecher, Uncle Tom's Cabin, or Life Among the Lowly. With illustrations by E. W. Kemble. New York: Riverside Press, 1891. Courtesy, Clifton Waller Barrett Library of American Literature, Special Collections, University of Virginia Library. 


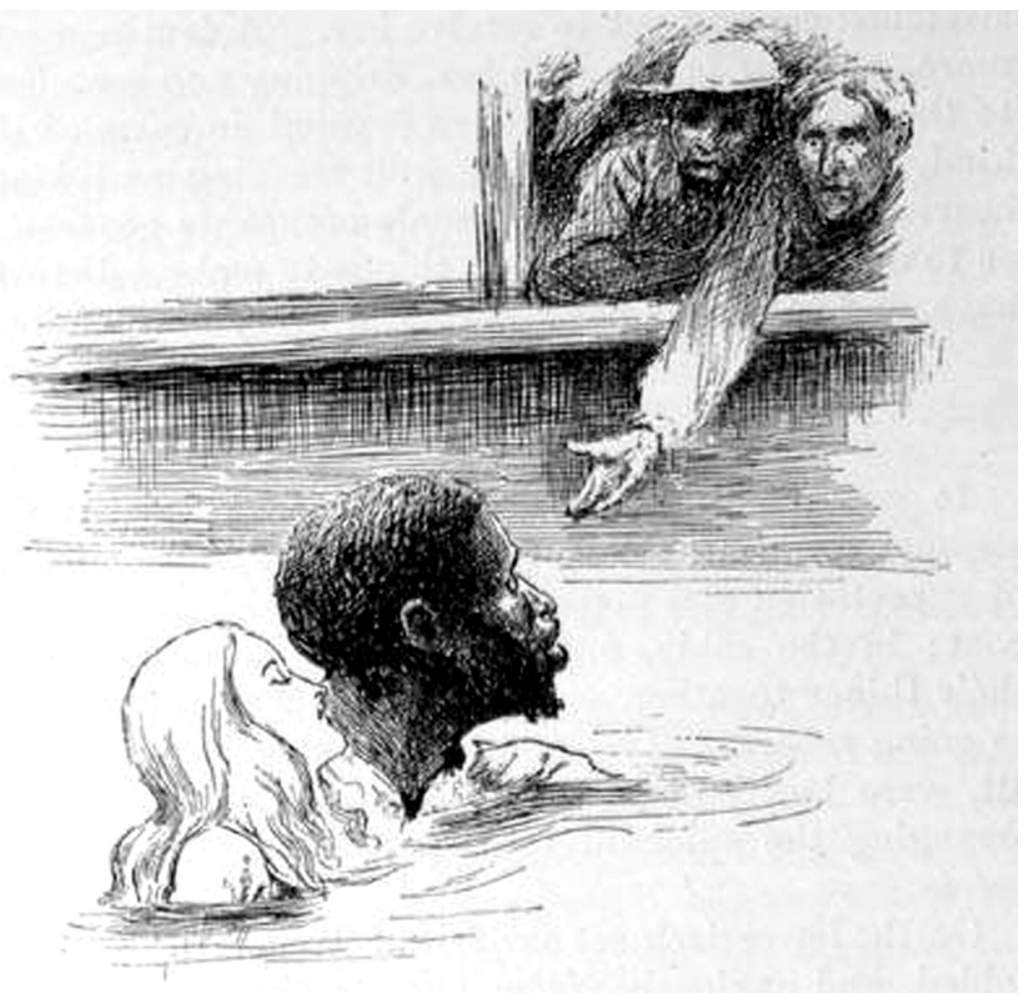

FIGURE 5. Tom rescuing Eva from the Ohio River waters. Stowe, Harriet Beecher, Uncle Tom's Cabin, or Life Among the Lowly. With illustrations by E. W. Kemble. New York: Riverside Press, 1891. Courtesy, Clifton Waller Barrett Library of American Literature, Special Collections, University of Virginia Library. 
river waters, rendered opaque, keep us from seeing where and how Tom supports Eva's body. Tom appears as part of the composition's diagonal arrangement, which extends from a fading Eva in the lower left to a stranger's outstretched arm in the upper right. Balanced in the composition, Tom is a dark, central figure, flanked by paler faces; he is one agent out of many in rescuing Eva, and not a hero saving her singlehandedly.

A second image shows Tom supporting Eva, but doing so after her death, as Tom regards a figure whom he cradles to his bosom (see Figure 6). Though the tenderness in his face reflects his mourning, this image stands in for multiple episodes that treat Tom's intense emotional connections with Eva but that pass without illustration from Kemble. In fact, Kemble bypasses all of the novel's passages that describe Eva teaching Tom to read the Bible and learn to write. Though he will depict a reformed Topsy as a missionary who writes on a tablet as eager, bare-chested boys absorb her lessons, Kemble does not show Eva as the teacher, and Tom as the student, in an interracial literacy lesson. Kemble, who had avoided depicting Jim's intimate interactions with the adolescent Huck, also avoids depicting Tom with the adolescent Eva. Viewers see Tom physically supporting Eva, not playing a supporting role in the novel's action.

Kemble's remaining images of Tom also show a debonair, formally dressed figure. The edition's readers see Tom kneel before a seated St Clair. They see him consigned to the margins of an image as St Clair plays piano at the image's center. In one image, Tom and Augustine St Claire clasp hands in expressing agonizing grief for the recently departed Eva. Tom stands as Augustine adopts the kneeling posture of a repentant in another image, which echoes temperance literature. A slave, who might or might not be Tom, submits to the demeaning inspections of a slave buyer, who might or might not be Legree (see Figure 7). Even counting those images that might be Tom, Kemble's edition includes only a handful of pictures of the title character. As Stephen Railton notes of these images, readers do not see violence visited upon Tom, or see any depictions of 


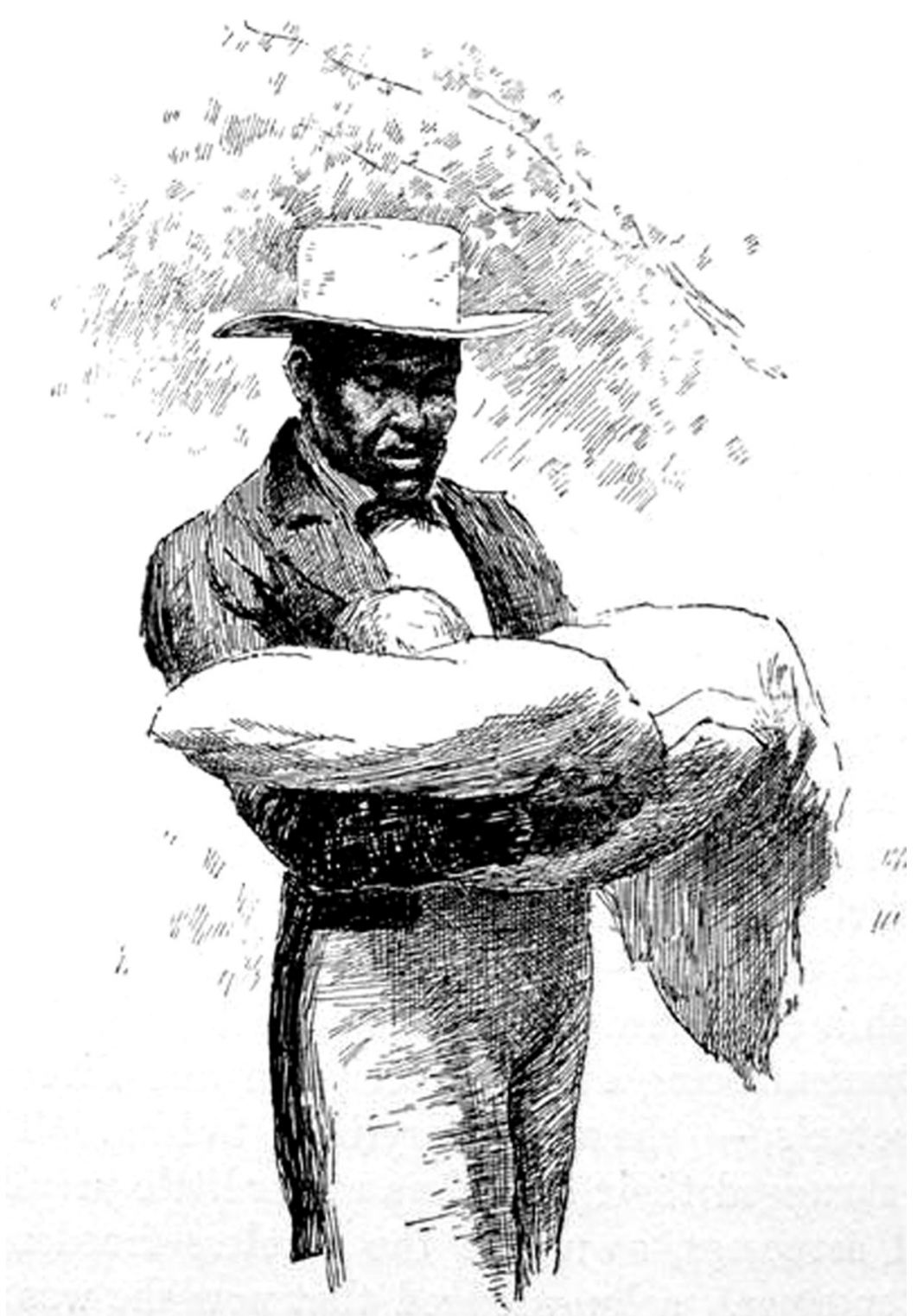

Fig U RE 6. Tom cradling a deceased Eva. Stowe, Harriet Beecher, Uncle Tom's Cabin, or Life Among the Lowly. With illustrations by E. W. Kemble. New York: Riverside Press, 1891. Courtesy, Clifton Waller Barrett Library of American Literature, Special Collections, University of Virginia Library. 


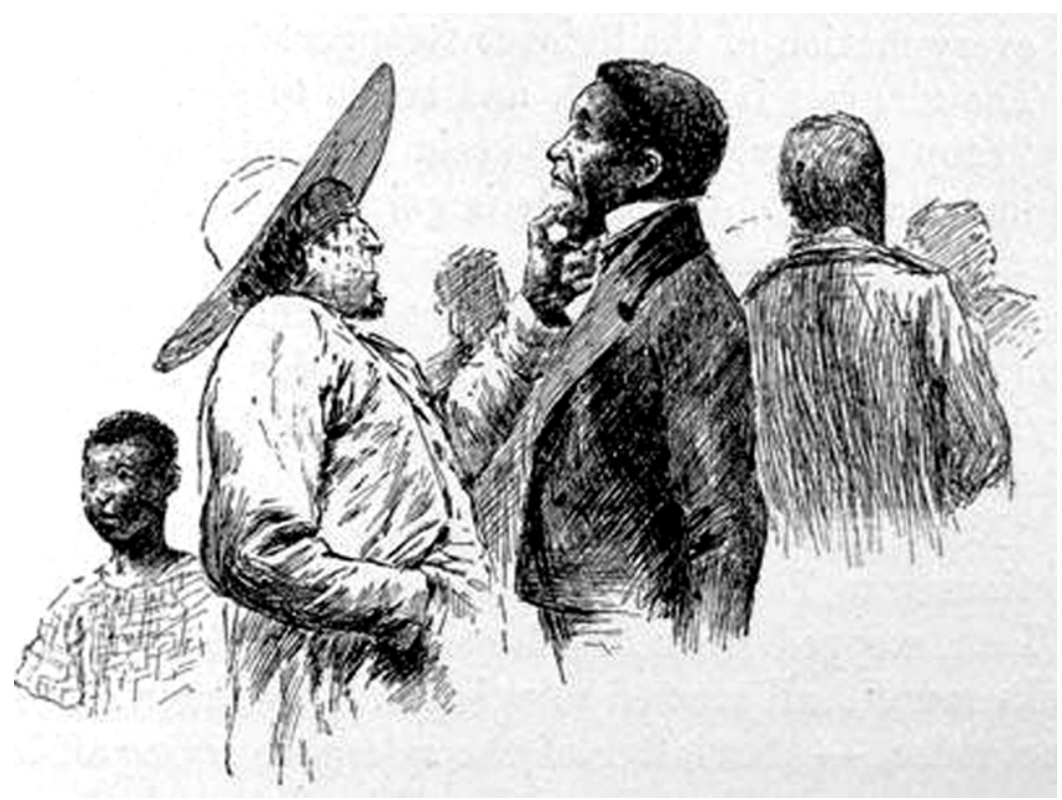

FIGURE 7. A depiction from Kemble of a slave buyer (possibly Legree) inspecting a slave. Stowe, Harriet Beecher, Uncle Tom's Cabin, or Life Among the Lowly. With illustrations by E. W. Kemble. New York: Riverside Press, 1891. Courtesy, Clifton Waller Barrett Library of American Literature, Special Collections, University of Virginia Library. 
Tom's death. ${ }^{13}$ As Beverly R. David first observed, Kemble's imagery for Adventures of Huckleberry Finn took the edge off of potentially disturbing images that might have shown more mature or more violent subject matter, making the visual-verbal text more suitable for children. ${ }^{14}$ Kemble similarly reconciles $U n$ cle Tom's Cabin and Gilded Age sensibilities, hiding the book's more violent scenes and omitting some of Tom's most intimate moments with Eva in the process.

Though Kemble devotes scant attention to Uncle Tom, he renders abundant imagery of other slaves, who seem to correspond to contemporary stereotypes and remain irrelevant to the novel's action. Marie St Clair's challenge in chapter 29 that she will show a slave that "she's no better than the raggedest black wench" (Uncle Tom's Cabin, p. 329) prompts Kemble to illustrate just such a hapless wench, who appears in an exaggerated rendering of threadbare rags, stooped posture, and emaciated demeanor (see Figure 8). An offhand remark that "'bout every nigger of us keeps a pup of some natur or uther" (p. 61) leads to a rough rendering of just such an endearing pup (see Figure 9). Kemble looks away from Tom's most significant actions, chooses seemingly random details for "local color," and draws figures that his contemporaries knew as mammies, darkies, and pickaninnies. Several reviews single out Kemble's images of African American children, as when one writer explains: "The larger part of Mr. Kemble's many illustrations are simply sketches inserted in the text. Of these the considerable number which depict the fascinating little negro girls and boys are easily the most effective; others, which represent negroes and negresses in various aspects of plantation life, are not bad." 15 A literary work, written to free children from the horrors of slavery, gains recognition for visual images that depict boys and girls experiencing slavery as mirthful delight.

\footnotetext{
13 See Stephen Railton and the University of Virginia, Uncle Tom's Cabin and American Culture: A Multi-Media Archive, Univ. of Virginia Libraries, 2007, available online at $<$ www.iath.virginia.edu/utc/ $>$.

${ }^{14}$ See David, "The Pictorial Huck Finn: Mark Twain and His Illustrator, E. W. Kemble," p. $35^{1 .}$

15 [Anon.], "Uncle Tom's Cabin Illustrated," Literary World, 23 (1892), 19.
} 


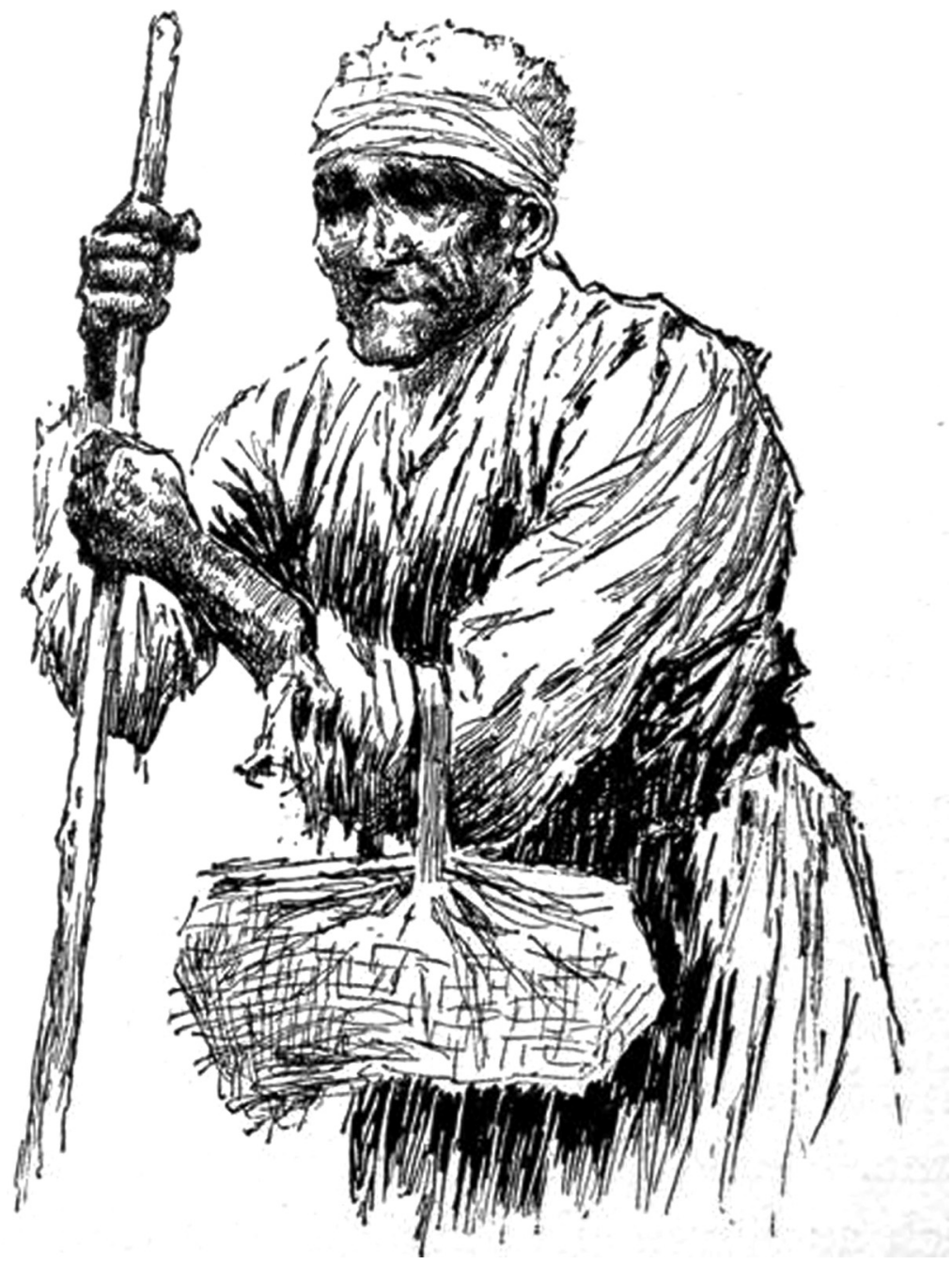

Fig U RE 8. One of Kemble's images from Uncle Tom's Cabin. Stowe, Harriet Beecher, Uncle Tom's Cabin, or Life Among the Lowly. With illustrations by E. W. Kemble. New York: Riverside Press, 1891. Courtesy, Clifton Waller Barrett Library of American Literature, Special Collections, University of Virginia Library. 


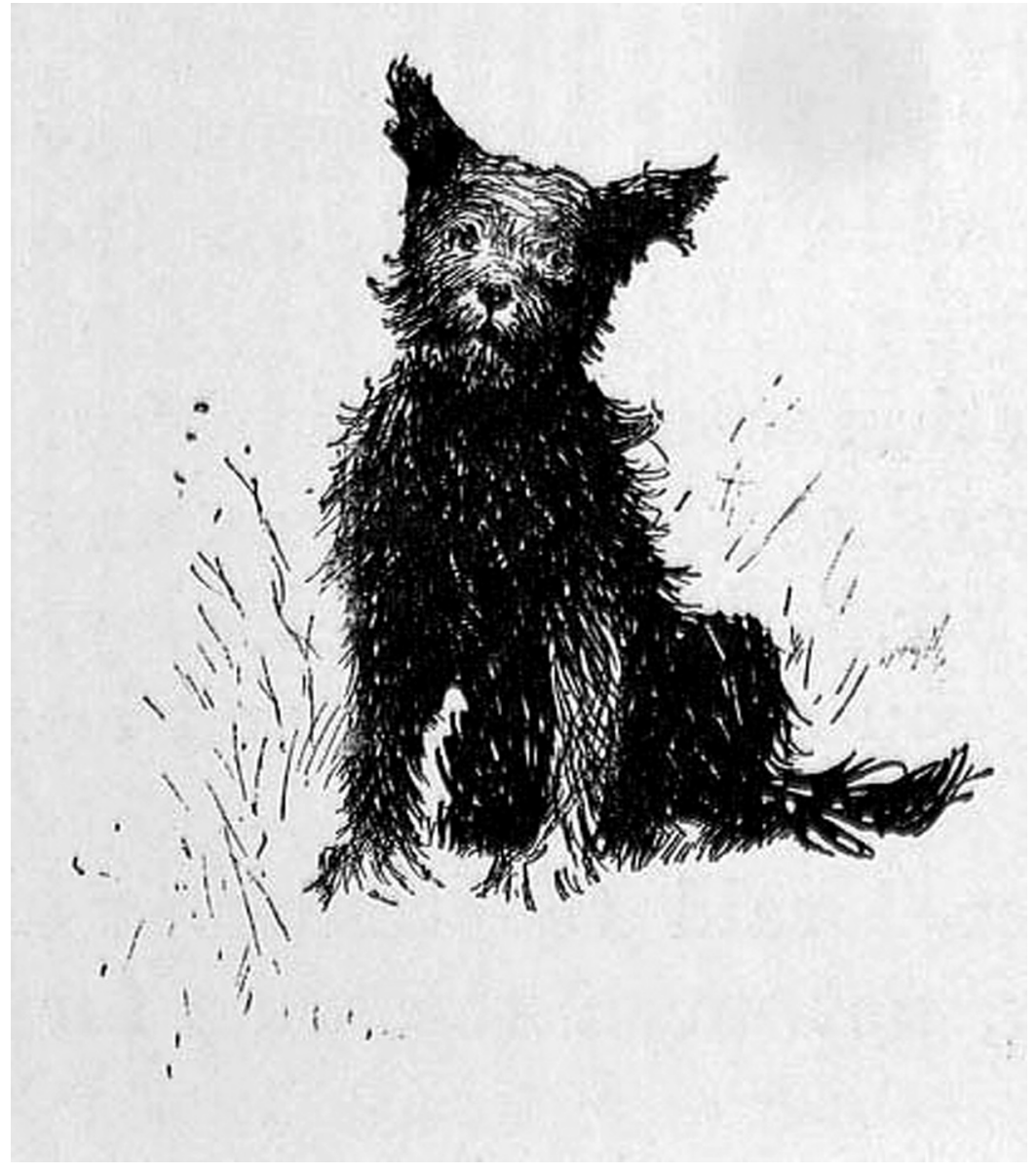

FiguRE 9. One of Kemble's images from Uncle Tom's Cabin. Stowe, Harriet Beecher, Uncle Tom's Cabin, or Life Among the Lowly. With illustrations by E. W. Kemble. New York: Riverside Press, 1891. Courtesy, Clifton Waller Barrett Library of American Literature, Special Collections, University of Virginia Library. 
Kemble's figures, irrelevant to the novel's main action though they might be, also show a surprising degree of variation in facial expression and individuation among the adult slaves. Kemble is at pains to show distinct persons who are subject to slavery, and not slavery creating a homogeneous type. Even images dubbed "One of the Servants" and "Another Servant" trouble to distinguish the figures with unique and expressive physiognomies (see Figures 10 and 11 ). Though a stereotypical butler figure appears all too often (see Figure 12), others suggest individuality and interiority. Kemble lends sentient expression to women bearing baskets of laundry on their heads. He renders chiaroscuro photogravures of black laborers in swamps and cotton fields. He shows as much variation in attitude and character among his black figures as one sees among his white figures. The artist who treated Jim reductively and stereotypically in 1885 develops multiple variations on his racial types by 1891 , and lends individuated expression to Prue and Topsy.

Conventions that were current at the time for illustrations help to explain some of Kemble's artistic liberties. If the novel's characters and scenes had already become overly familiar figures in Gilded Age popular culture, then marketing strategy would encourage unfamiliar, innovative images as a means of repackaging passé material. Previous editions of Uncle Tom's Cabin had depicted Eva's literary lesson for Tom on the cover of the book-partially accounting for Kemble's omission of the image here. Stowe's most loyal readers would already possess copies of the novel-making it likely that Houghton Mifflin aimed this edition toward people outside of her most immediate audiences. In its January 1892 review, The Literary World declared: "In this beautiful form Uncle Tom's Cabin will, if it is possible, increase its range of readers, whom it will still deeply affect by its pathos and its eloquence, nearly thirty years after the Emancipation Proclamation" (p. 19). The review's conditional modifier, "if it is possible," seems hard to parse: either the novel is already so successful that the publishers cannot hope to broaden its appeal, or remaining audiences lay so far beyond the novel's expected "range of readers" that they would never purchase the edition, no matter how it was marketed. In either case, Houghton Mifflin and Kemble do not supply customary imagery 


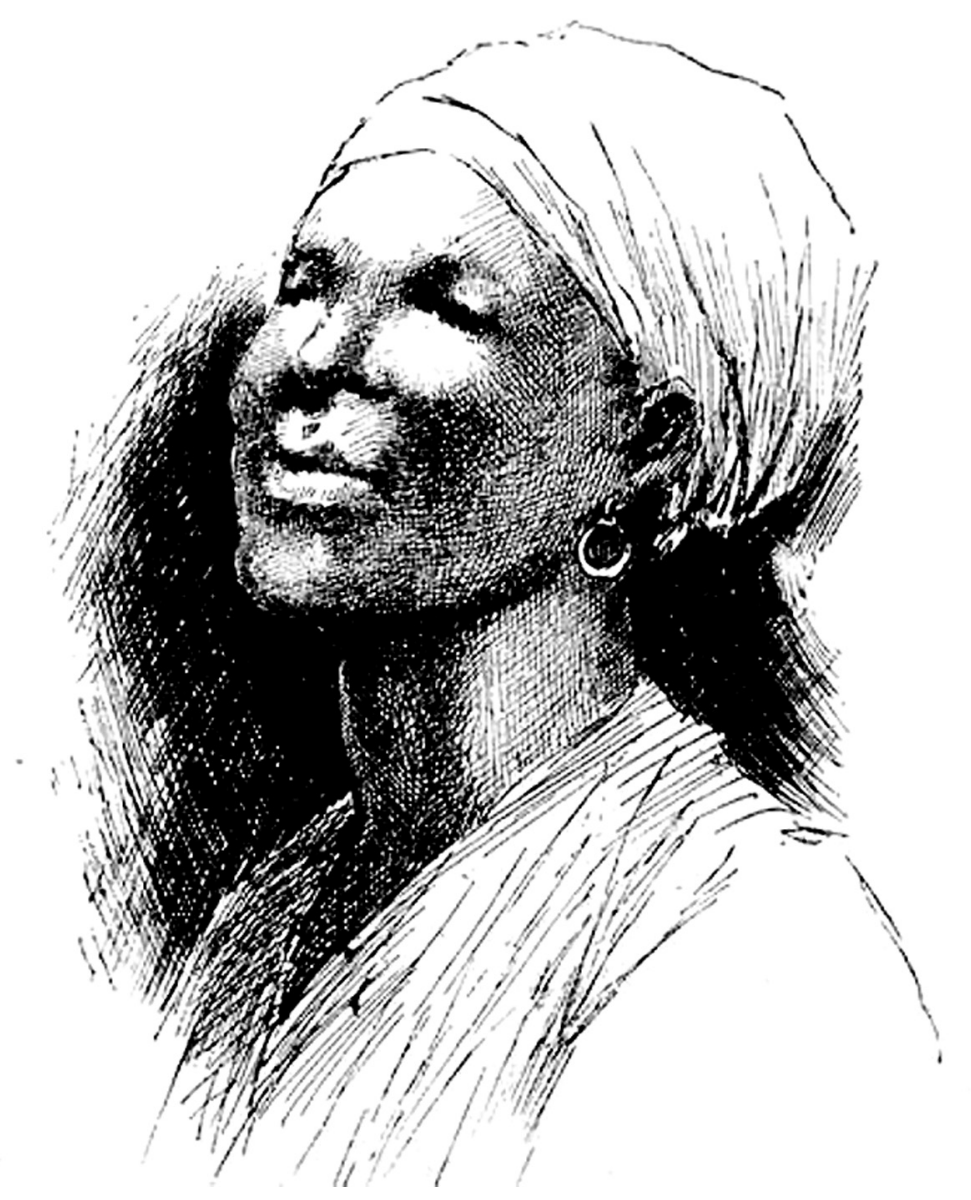

F I G U RE 10. One of Kemble's images from Uncle Tom's Cabin. Stowe, Harriet Beecher, Uncle Tom's Cabin, or Life Among the Lowly. With illustrations by E. W. Kemble. New York: Riverside Press, 1891. Courtesy, Clifton Waller Barrett Library of American Literature, Special Collections, University of Virginia Library. 


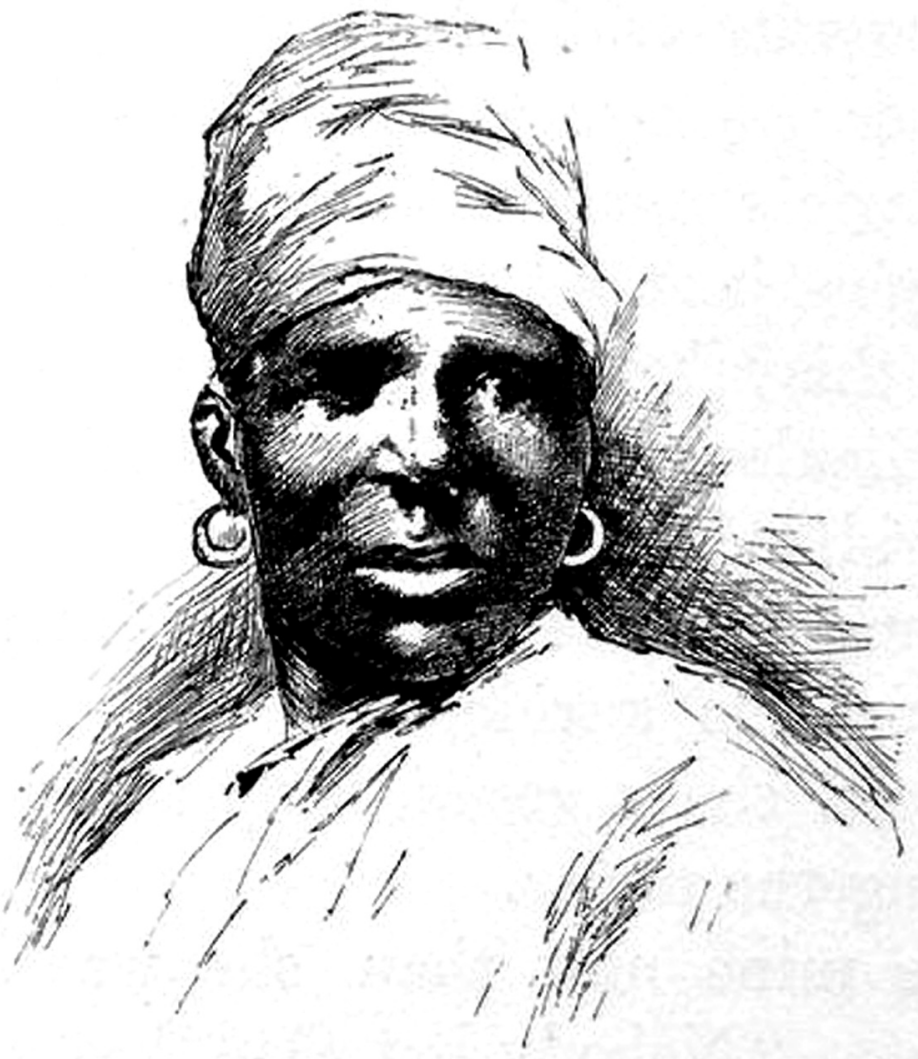

FIGURE 11 . One of Kemble's images from Uncle Tom's Cabin. Stowe, Harriet Beecher, Uncle Tom's Cabin, or Life Among the Lowly. With illustrations by E. W. Kemble. New York: Riverside Press, 1891. Courtesy, Clifton Waller Barrett Library of American Literature, Special Collections, University of Virginia Library. 


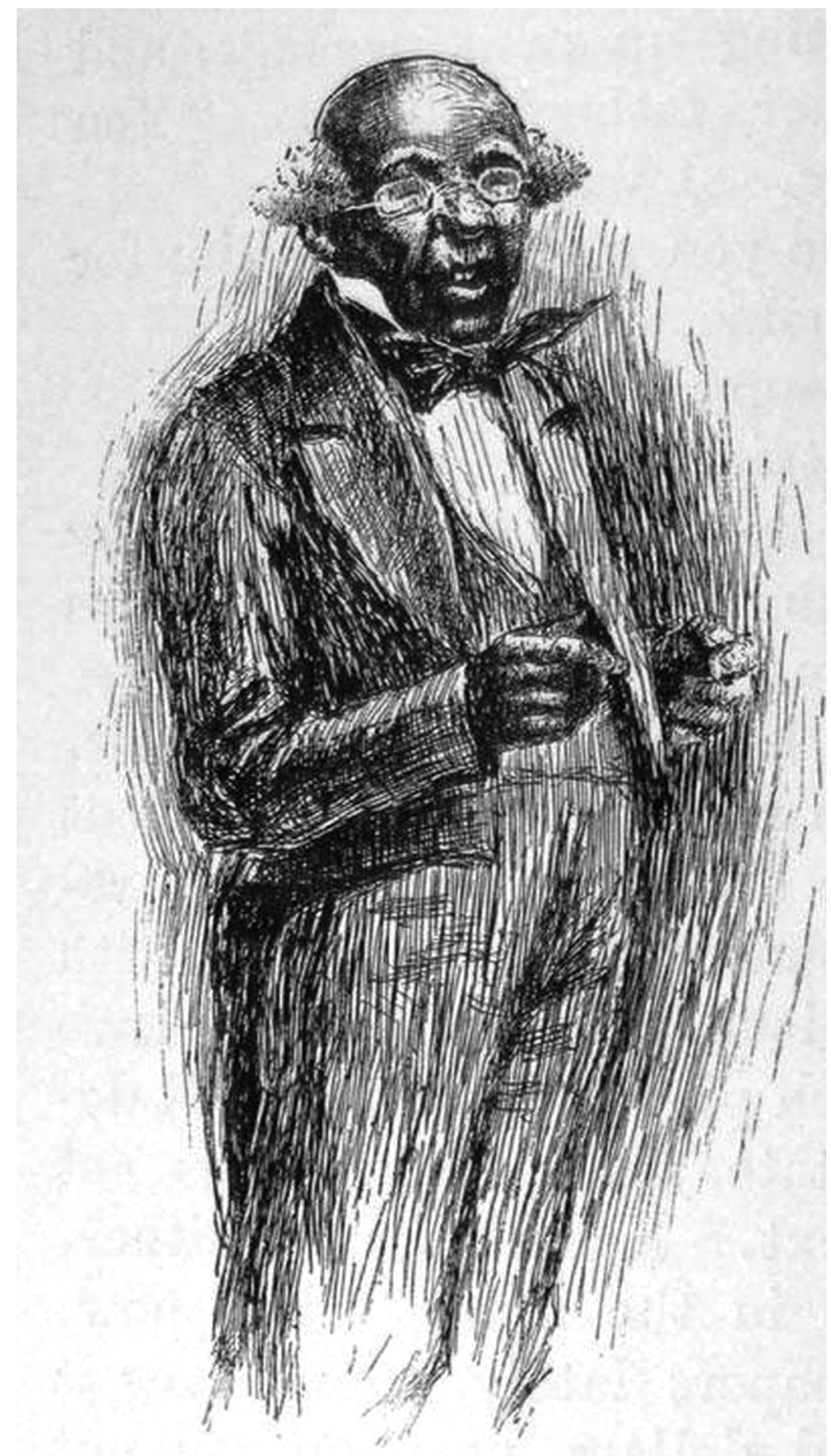

FiguRE 12. One of Kemble's images from Uncle Tom's Cabin.

Stowe, Harriet Beecher, Uncle Tom's Cabin, or Life Among the Lowly. With illustrations by E. W. Kemble. New York: Riverside Press, 1891. Courtesy, Clifton Waller Barrett Library of American Literature, Special Collections, University of Virginia Library. 
to already loyal audiences, but instead attempt to render a new Uncle Tom's Cabin for readers less familiar with the work.

Contemporary aesthetic theories that governed reception of Kemble's images conceived of illustrations as gentle departures from prose texts, as visual complements rather than direct competition for the verbal imagery. John Ruskin had influentially called for illustrations that did not re-create the same scenes that fictions already described, but that offered opportunities for illustrators to work within the spirit of a prose novel, as he or she elaborated upon the letter of the text. "According to Ruskin," Julia Thomas explains, "there are definite dangers associated with illustrations that attempt to take the text at its word and aim faithfully to reproduce its details: they are superfluous diversions that weaken the reader's attention and lead to a 'feverish thirst for excitement" (Pictorial Victorians, p. 26) ${ }^{16}$ Ideally, visual elements broadened the appeals of verbal texts, inviting readers to conspire in the subtle prose secrets that explained manifest visual designs.

In Kemble's case, irrelevant imagery or background material seems oddly emphasized, while expected, already familiar scenes seem elided. Kemble in effect reproduces the same kind of imagery that he had used for works by Joel Chandler Harris, Thomas Nelson Page, and George Washington Cable, as if he is attempting to attract a class of Southern-sympathizing readers to a Northerner's abolitionist novel. In turn, Kemble refrains from reproducing the imagery that this class of readers would find objectionable, omitting interrelations between races, affection across generations, and literacy lessons for slaves. Kemble's Uncle Tom's Cabin reflects progressive politics for race relations in antebellum contexts; but its omissions reflect reactionary politicsgrandfather clauses, poll taxes, literacy tests—that qualified these advances. Even as the edition further canonizes Stowe's novel, Kemble's designs conceal its original political character.

Stowe spoke highly of Kemble's and other artists' graphic illustrations of her works. Stowe expressed "great satisfaction" for receiving a copy of an illustrated 1885 edition of Uncle Tom's Cabin: "So pretty a book," she wrote, "at so cheap a price ought to command a sale \& from the letters constantly coming to me

\footnotetext{
${ }^{16}$ The Ruskin quotation is from The Cestus of Aglaia $\left(1865^{-66}\right)$.
} 
in every mail I judge the interest in it is unabated." ${ }^{7}$ Stowe wrote in a dedication copy to the illustrator of her 1891 edition: "To Mr. Kemble, with grateful acknowledgement for his faithful and admirable work in illustrating 'Uncle Tom's Cabin.'"18 Far from a verbal purist, Stowe welcomed efforts to add to the visual appeal of her works. ${ }^{19}$ Modern readers might sense an incongruity between Twain's progressive politics in Adventures of Huckleberry Finn and Kemble's illustrations for the novel, but Gilded Age readers and reviewers, including Stowe, saw an appropriate match between the rhetoric of Uncle Tom's Cabin from $185^{2}$ and Kemble's representations in 1891 . In the same group of images, Kemble shows fidelity both to Uncle Tom as Stowe originally perceived him and to "Uncle Tom," as Gilded Age readers had revised his political and symbolic meanings.

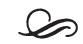

Kemble's career in the early 1890 involved him in a battle over representative "types," but not in the way that many modern scholars have understood them-and not in a way that involved black stereotypes, but rather one that involved ethnically intermingled "types" of impoverished whites. Twain scholars often turn to an Atlanta Constitution article from September 1892, less than a year after the release of Kemble's Uncle Tom's Cabin, in which Joel Chandler Harris, prolific author and creator of the Uncle Remus folklore series, prefers illustrator Arthur Burdett Frost's illustrations over Kemble's work. Frost is, according to Harris, "our one American book illustrator, our one delineator of American character and the humor-not the fun-that

${ }^{17}$ Harriet Beecher Stowe, letter to H. O. Houghton, 3 September $188_{5}$, quoted in Joan D. Hedrick, Harriet Beecher Stowe: A Life (New York: Oxford Univ. Press, 1994), p. 395 .

18 Stowe, quoted in Martin, "Edward Windsor Kemble, a Master of Pen and Ink," p. 61 .

${ }^{19}$ Hedrick notes that "in 1889 Stowe suffered a major decline that left her with diminished faculties" (Harriet Beecher Stowe: A Life, p. 397), such that Stowe's daughter Hatty remarked in a letter that "Intellectually she is not now above a child of two or three years" (Hattie Stowe, letter, 29 January 189o, quoted in Harriet Beecher Stowe: A Life, p. 397). Kemble's dedication copy is probably best understood as polite reception of the work, and not an expression of Stowe's full critical judgment. 
underlies it. He stands alone." Elaborating, Harris remarks that "our magazines swarm with" caricature, defined as the work of "those who picture forth what they please to call types." "What is a type worth in art?" he then asks in an often-quoted passage; "Nothing whatever. It may possess a scientific value, but this is for the ethnologist or the biologist to determine. Neither fictive nor illustrative art has any business with types. It must address itself to life, which is character; to the essence of character, which is individuality. Missing these it misses its true function." 20

Preferring the individualized and idiosyncratic over the abstracted and stereotyped, Harris implicitly values Frost's delineated figures over Kemble's racial abstractions. Harris had turned from collaborating with Kemble for his early works to preferring Frost's images for his own publications, including the Uncle Remus volumes. Many readers have heartily agreed with him, with Earl F. Briden stating that in the editorial Harris had "defined the stylistic requirements" that Briden himself "would set for an illustrator of Huck's story" ("Kemble's 'Specialty,"” p. 12). Briden's reasoning casts doubt on Twain's progressive politics, suggesting that Twain had faltered in working with Kemble and not with Frost, whom Harris had called the quintessentially "American" delineator of individuals.

Delineated individuals surely outstrip rough, racist abstractions in visual and verbal art. But such preferences stem from twentieth-century ethics of minority representation more than from nineteenth-century circumstances of race relations, which inform Harris's Atlanta Constitution editorial. A larger historical context, again involving Kemble's "types" and Frost's individuals, suggests a different explanation for Harris's preferences and for Kemble's illustrations for Uncle Tom's Cabin. In February 1891 Kemble had illustrated an article that Claire de Graffenried had published in Century Magazine entitled "The Georgia Cracker in the Cotton Mills." In this article de Graffenried approaches Georgia cotton mills as Rebecca Harding Davis had approached West Virginia iron mills thirty years earlier, venturing into the mills' squalid settings, echoing

\footnotetext{
${ }^{20}$ [Joel Chandler Harris], "An American Artist, ” Atlanta Constitution, 26 September 1892 , p. 4 .
} 
muckraking indictments of industrial conditions, and accounting for new "types" of laborers. De Graffenried declares:

The race that tends the spindles of the cotton-growing States is altogether unique. To describe it, geographical boundaries must be effaced and national peculiarities ignored; for the blood of the followers of Cavaliers in Maryland, noblemen in Virginia, Swiss and palatines in North Carolina, and Huguenots in the Palmetto State blends with that of the impecunious gentlemen brought by Oglethorpe to Georgia, and everywhere crops out in one quaint, baffling, original, unchangeable type. ${ }^{21}$

"Type," then, as the word appears in the discourse that Harris responds to in his Atlanta Constitution editorial, designates oncedistinct ethnic lines-Virginia's landed gentry, South Carolina's Huguenots, former inmates of British debtors' prisonsblending together over the course of history. De Graffenried brands the resulting "type" as "Crackers," and explains that a class of poor whites, who were excluded from slave-based, cottonbased antebellum economies, amalgamated their ethnic heritages, while empowered, slaveowning scions evidently looked the other way. Generations later, de Graffenried summarizes, "The crackers of our time are an impressive example of race degeneration caused partly by climate, partly by caste prejudices due to the institution of slavery" ("Georgia Cracker, p. 484). The Century pages that bear de Graffenried's epithets "race degeneration," "laziness," and "ignorance" also show Kemble's images of "A Type," "Types," and "A Race Problem" (see Figures 13, 14, and 15). Haggard expressions and supposed indications of ethnic intermarriage all make a pervasive and stultifying exhaustion the sole distinguishing feature of this "type."

The Atlanta Constitution and its readers felt that they must respond to this attack on Georgia culture; Harris's editorial, preferring Frost's individuals to Kemble's “types," forms part of the response. Multiple letters to the editor defended the cotton mills, rejected de Graffenried's thesis on the origin of the "Cracker" class, and focused most directly on Kemble's

${ }^{21}$ Clare de Graffenried, "The Georgia Cracker in the Cotton Mills," Century Magazine, $4^{1}(1891), 4^{84}$. 


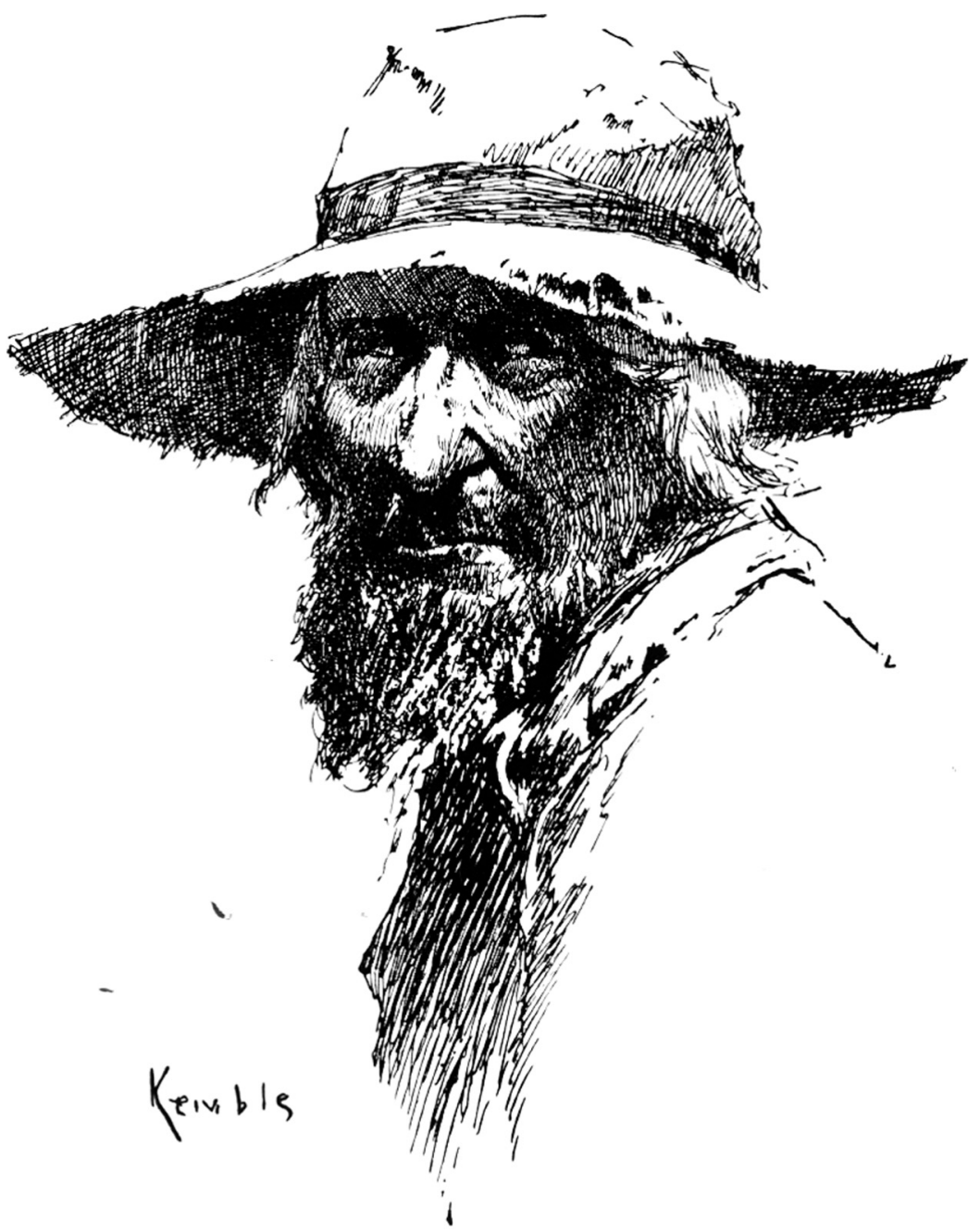

A TYPE.

FIGURE 13. Kemble's rendering of a "type," a working-class Southerner deemed to belong to the "Cracker" class of Georgians. From Clare de Graffenried, "The Georgia Cracker in the Cotton Mills." Century Vol. 41 No. 4 (February, 1891 ), page 486. Cleveland State University libraries, Cleveland, Ohio. 


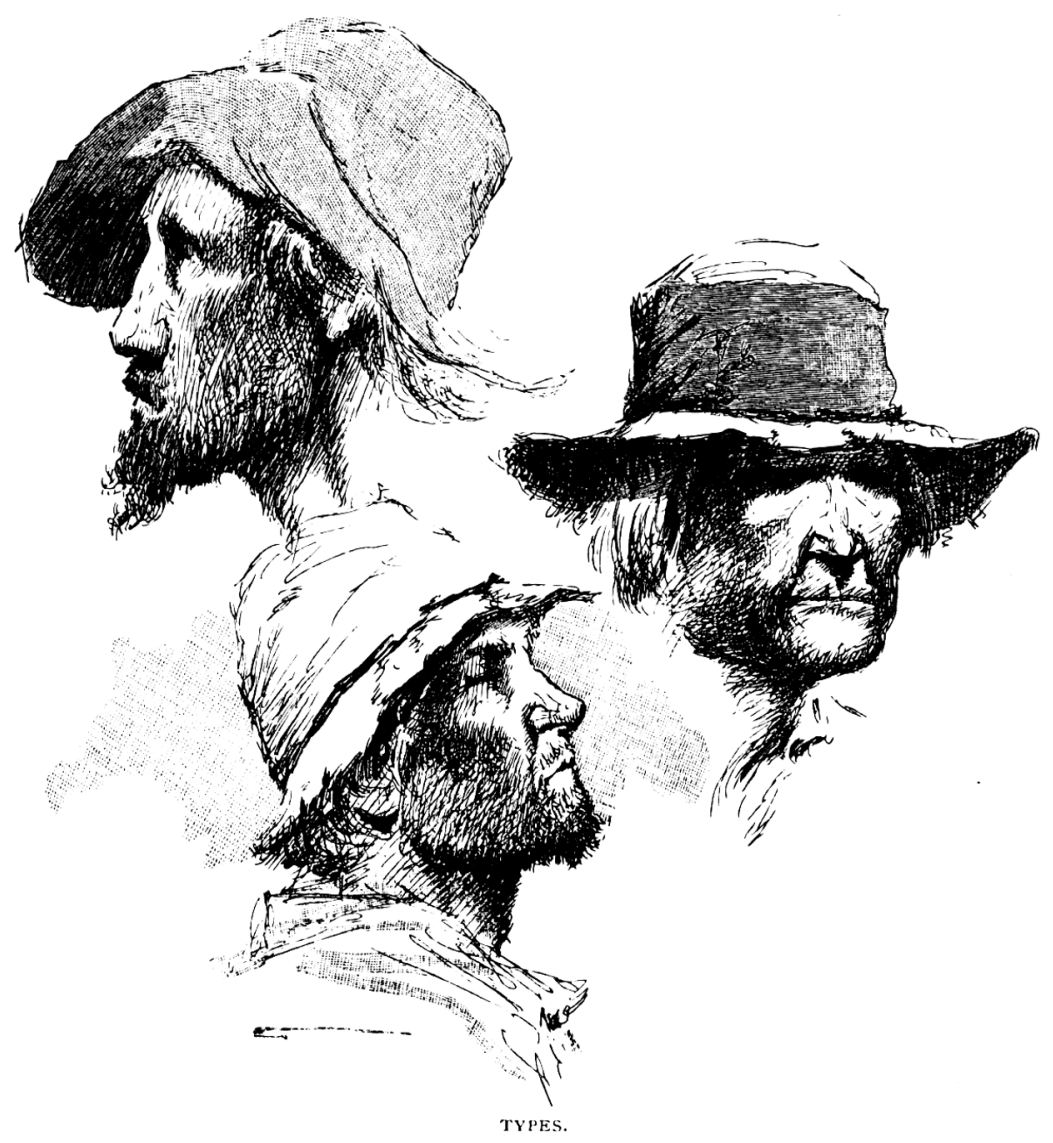

F I G U RE 14. Similar Southern "types" from Kemble. From Clare de Graffenried, "The Georgia Cracker in the Cotton Mills." Century Vol. $4_{1}$ No. 4 (February, 1891), page 487. Cleveland State University libraries, Cleveland, Ohio. 


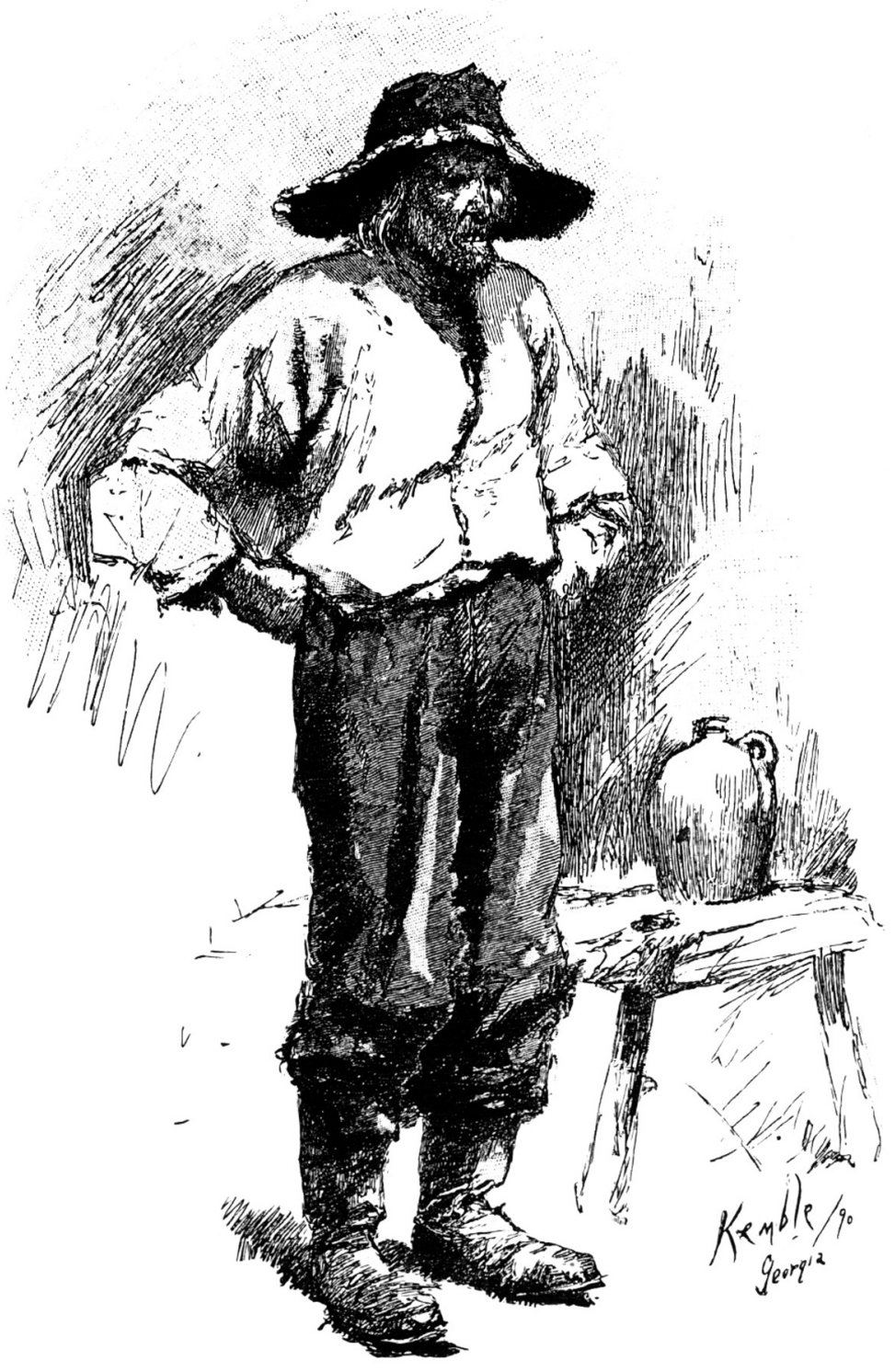

A RACE PROBLEM.

FIGURE 15. This rendering of a white Southern "type" from Kemble includes the label "A Race Problem." From Clare de Graffenried, "The Georgia Cracker in the Cotton Mills." Century Vol. 41 No. 4 (February, 1891), page 49o. Cleveland State University libraries, Cleveland, Ohio. 
imagery, with one calling them "hideous distortions." ${ }^{22}$ Kemble wrote a letter to the editor as a reply, insisting that the Georgia mill workers, whom he observed directly as he sketched, "were with a very few exceptions, shabbily dressed, pale and sallow, haggard looking and snuff-dippers; while the men and boys either loafed outside the mill or near some convenient store step." Kemble concludes that everyone he saw in the mills "was confirmatory of Miss de Graffenreid's [sic] article." ${ }^{23}$ Kemble's sketches, then, suggest that white Southerners had intermingled ethnic groups in a blending of bloodlines, which thencurrent discourse labeled "a race problem." Kemble's "types" raised the ire of the Atlanta Constitution and its readers, not for what they implied about blacks who were insufficiently delineated, but for what they hinted about whites who were supposedly amalgamated, ethnically indistinct.

Two additional documents, which Harris refers to in his Atlanta Constitution editorial, lend further background to this implicit dismissal of Kemble's "types" and embrace of Frost's figures. In words that Harris echoes, H. C. Bunner writes in Harper's in October 1892: "The most casual observer must take note of Mr. Frost's success in producing atmospheric effects that are unmistakably and characteristically American.” Bunner speaks instead of a "native individuality" characteristic of this type, assuring readers-who apparently had doubts—-that "on both the father's and the mother's side [Frost's] ancestry is American back to 1633 , or thereabouts." 24 "Individuality" carries an ethnic meaning rather than a multicultural one, as Bunner invokes "American" to denote an unalloyed Puritan stock, an undivided Anglo American inheritance, which Frost embodies in his person and depicts in graphic illustrations. These remarks appear beneath Frost's image of "Georgia Crackers," whom he treats with a stylized romanticism, contrasting with Kemble's crude depictions of their "type" (see Figure 16). Modern scholars scrutinize these

${ }^{22}$ Quoted in Martin, "Edward Windsor Kemble, a Master of Pen and Ink," p. $6_{5}$. The letters were originally published in the Atlanta Constitution, 25 May 1891, p. 4 .

${ }^{23}$ E. W. Kemble, letter to the Atlanta Constitution, 10 June 1891 , quoted in Martin, "Edward Windsor Kemble, a Master of Pen and Ink," pp. 65-66.

${ }^{24}$ H. C. Bunner, “A. B. Frost.," Harper's New Monthly Magazine, 85 (1892), 705 . 


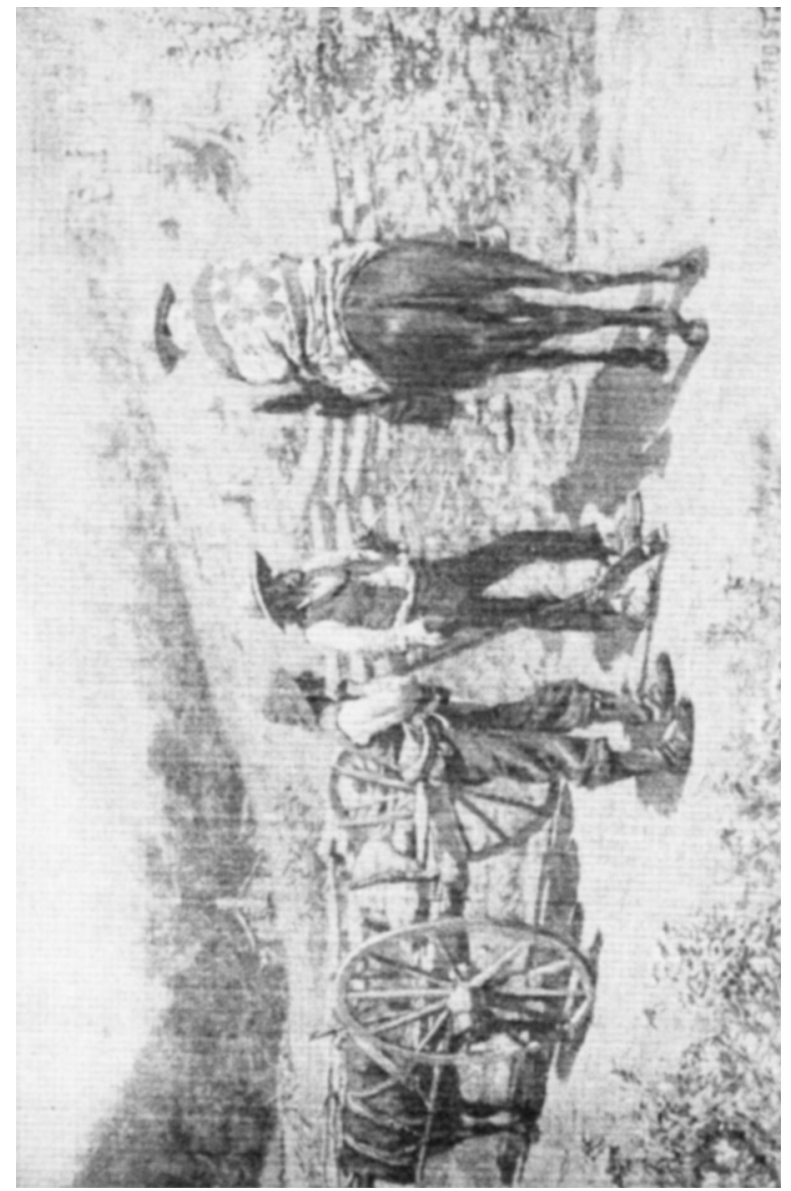

$\stackrel{巳}{\Xi}$

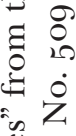

$\sum \infty$

范

ปิ

$\therefore$ a

$\frac{0}{2}$

ह

(4)

.

过若

के

ฐ $\frac{\pi}{2}$

ठิ

i

$8=$

0 o .

$\therefore$ 近

$\infty$ 을

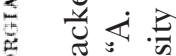

हैं

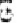

.

o $\Xi$

की

$\circlearrowleft \circlearrowright$

प्山.

อ

छ छ

ये

का

के

도.

๑ ق

<

¿ 00

$-.0$

되응

5 is 0

త 
illustrations for sensitive treatments of black subjects, but what mattered to Bunner and Harris was the implied ethnic heritage of the white "Cracker" class.

As for the second important document, Harris's editorial mentions Frost's work in depicting New England villages, but it does not name the article in question. In fact, Frost had illustrated Anna C. Brackett's "The Aryan Mark," which appeared in Harper's in 1892 and which commenced portentously, "There is nothing perhaps more distinctly Aryan than the New England town meeting." ${ }^{25}$ Observing a New England village's direct democracy and industrious diligence in carrying out its business, Brackett remarks:

we had before us the Aryan mark, and could not fail to think of those ancient, long-dead kinsmen of ours who ages ago came together in the same simple way to make the laws which they bound themselves to obey. Wherever the old town meeting is held, there we have the sign and seal of the mighty Aryan race, and of their idea of how they would govern themselves and their families." ("The Aryan Mark," p. 579)

A piece on Aryans-the term derives from the Sanskrit for "noblemen," recalling Western culture's Indo-European roots, aligning roughly with notions of Boston "Brahmins"-makes for distressing reading in a mainstream periodical some forty years before Hitler's rise to power. The distress becomes more acute when Brackett predictably turns to the analogy that "every genuine New England village is like an apple orchard"that is, "The trees are all apple-trees, and yet there is not one of them that does not insist upon its own individuality, and assert successfully its right to a special character of its own," until, as Brackett draws out the analogy, she sees in "every face its own peculiar traits" ("The Aryan Mark," pp. 581-82).

Graphic illustrations of New Englanders, by extension, should honor the commonly held traits of the inherited seed, as well as the unique idiosyncrasies of individual scions. Frost's accompanying images of "The Old Stage Driver," "The

${ }^{25}$ Anna C. Brackett, "The Aryan Mark: A New England Town Meeting," Harper's New Monthly Magazine, 85 (1892), 577 . 
Mechanic," and "The Honest Man" all seem to depict the same man, dressed differently and viewed from alternative angles (see Figures 17, 18, and 19). The same physiognomy recurs in each illustration, obviously reflecting a certain prominent nineteenth-century politician, closely associated with this archetype of the "honest man." Brackett's New England villagers, and Frost's graphic representations of them, betray a distinguishing "Aryan Mark" that signifies an unalloyed racial inheritance. Frost is rendering-and Harris is praising him for rendering-"American" "individuals" who retain a pure "Aryan" strain, rather than suggesting what many Georgians would have found unthinkable: that socioeconomic divisions had diluted original, seventeenth-century American characteristics and produced a degenerative "race problem," an undifferentiated, white Cracker "type.” African American stereotypes were not Harris's or Frost's central concerns here; Harris's Constitution editorial is actually praising Frost for refusing to depict an indistinct, ethnically mixed "type" of Southern whites.

When E. W. Kemble rendered imagery for Uncle Tom's Cabin later that same year, then, he was certainly aware of the implied meaning of "types." He surely knew that would-be purchasers of Uncle Tom's Cabin would peruse his images for individuality, typicality, and preservation of distinctive national features. Brander Matthews's review even entered into this fray in March 1892, when he wrote in Cosmopolitan that, with Kemble's illustrations, Stowe's novel "is now for the first time sent forth adorned with the sketches and pictures of an American who has given special study to the very varied negro types and to the equally divergent characteristics of the southern whites-Mr. Edward W. Kemble." ${ }^{26}$ For Matthews, and his readers, both black typicality and white Southern variation signify. Kemble's edition reflects interracial relationships in its re-creation of 185 os abolitionist contexts, as it also addresses intra-racial ones, as patrician and "Cracker" Southerners grappled with the 189 os legacy of the slave society that Stowe's novel depicts.

In the midst of this argument over the caricatured illustration of ethnic and racial "types," Kemble's rival, Frost, recipient

${ }^{26}$ Brander Matthews, "American Fiction Again," Cosmopolitan, 12 (1892), 637. 


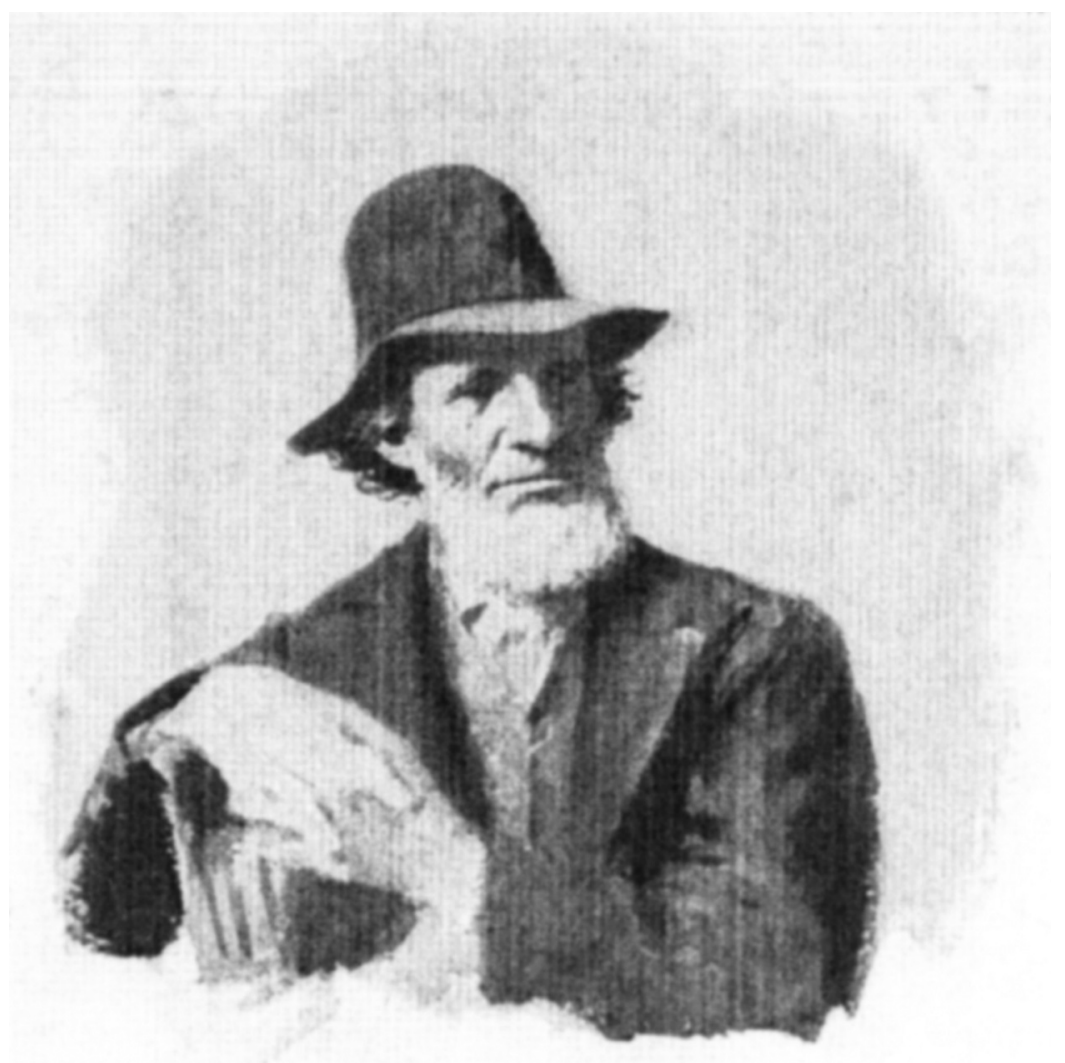

THE OLD STAGE-DRIVER.

Fi G U RE 17. A. B. Frost's "A Stage Driver." Note the similarity of the facial features in Figures 17, 18 and 19. From Anna C. Brackett. "The Aryan Mark: A New England Town Meeting." Harper's New Monthly Magazine Vol. 85 No. 508 (September, 1892), page 582. Cleveland State University libraries, Cleveland, Ohio. 


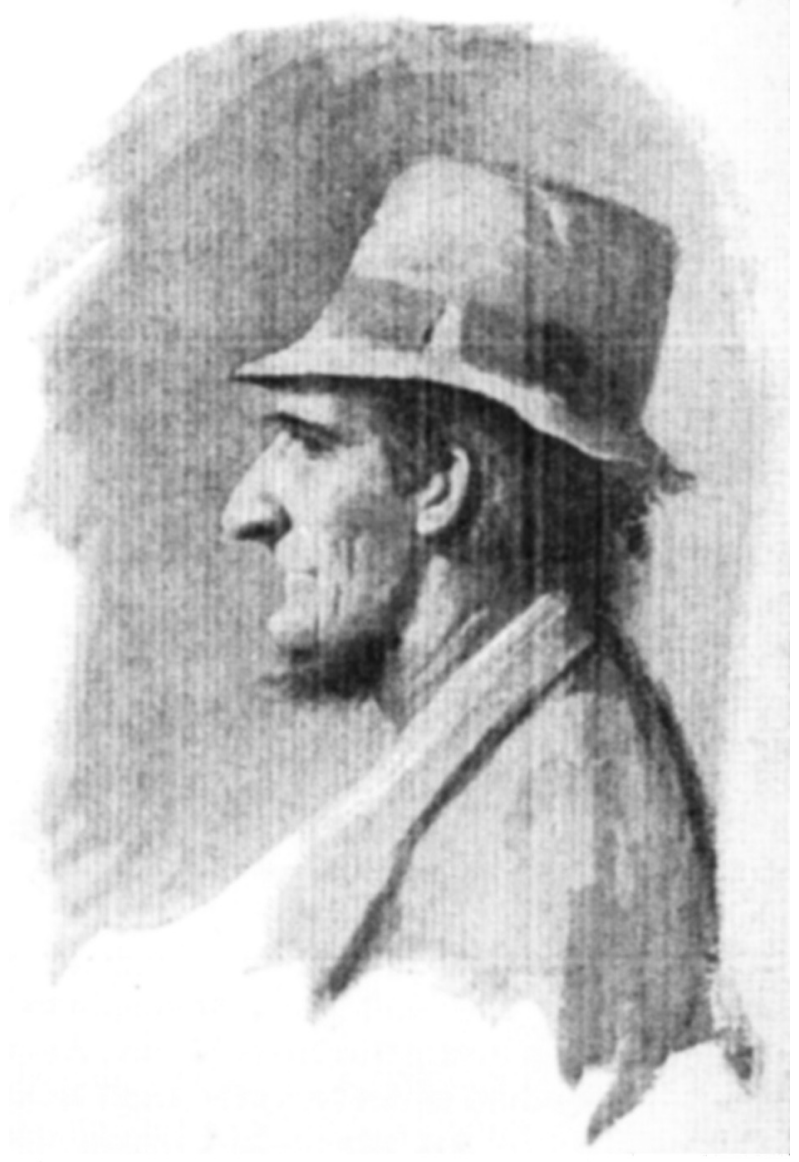

THE MEOHANHG

F I G U RE 18. From Anna C. Brackett. "The Aryan Mark: A New England Town Meeting." Harper's New Monthly Magazine Vol. 85 No. 5 o8 (September, 1892), page 582 . Cleveland State University libraries, Cleveland, Ohio. 


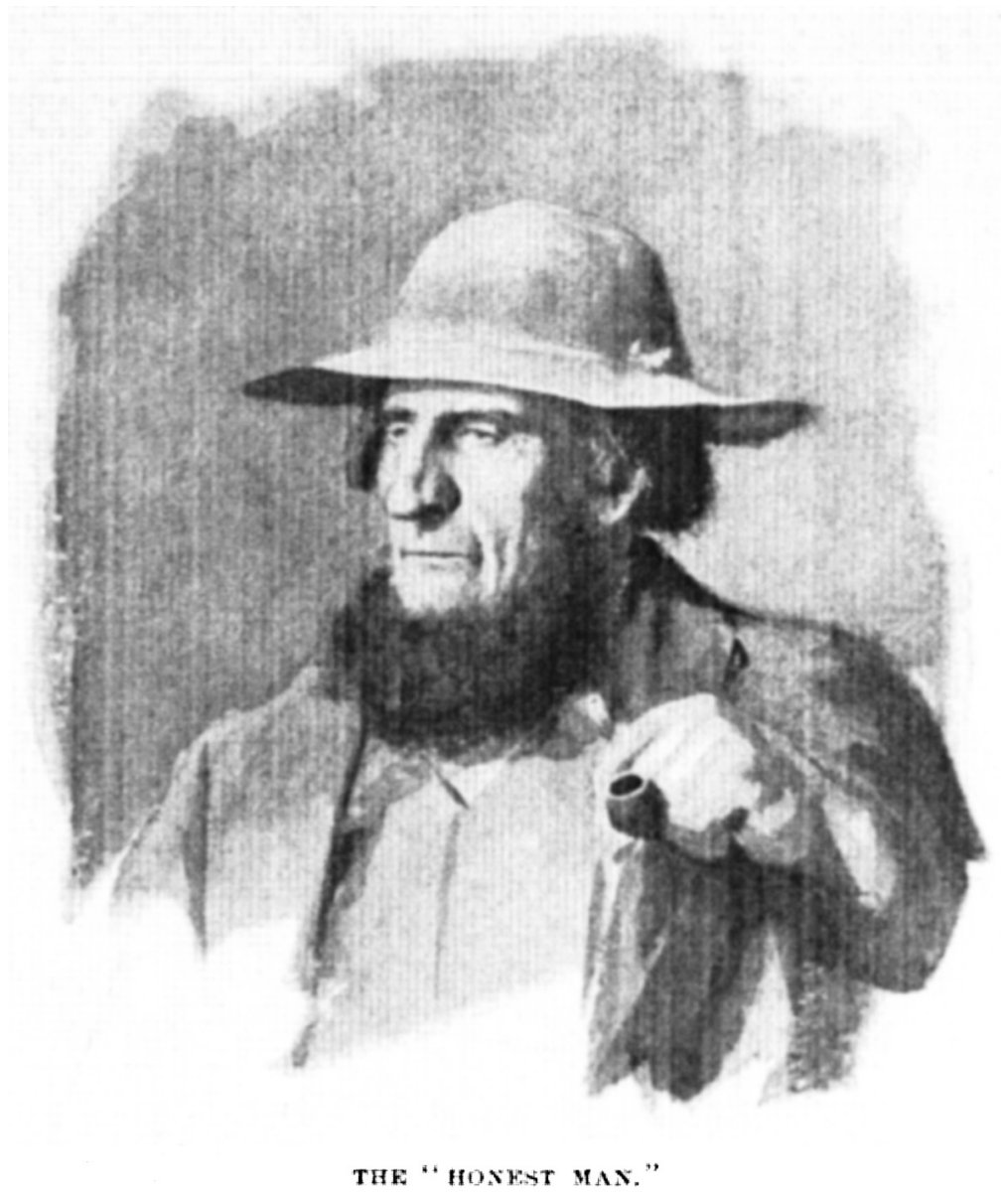

FiguRE 19. From Anna C. Brackett. "The Aryan Mark: A New England Town Meeting." Harper's New Monthly Magazine Vol. 85 No. 5 o8 (September, 1892), page 583 . Cleveland State University libraries, Cleveland, Ohio. 
of Harris's praise, rendered an image to accompany a Thomas Nelson Page short story in the September 1892 edition of Harper's. It demonstrates little or no difference between Kemble's and Frost's use of stereotype, collaboration with literary authors, or treatment of black figures (see Figure 20). Though Kemble's "specialty," African American figures, now seem like racist imagery, Frost, in the figure in the right half of his image, certainly shows no greater-and perhaps shows less-respect than Kemble shows in his black figures (see Figures 21 and 22). Though Twain's collaboration with Kemble sometimes casts doubt on Twain's progressive politics, this image by Frost introduces the work of Thomas Nelson Page, architect of Southern plantation fiction, author of two laudatory biographies of Robert E. Lee. "Guilt by association" with Kemble tarnishes Twain's image; Frost's partnership with Page should cast a dubious light on Frost as well. Harris praised Frost in 1892, and Briden seconded the praise in 1988, preferring Frost's individuals to Kemble's "types"; but, judging from these images, Kemble seems just as likely a choice as Frost for illustrating Twain. Such imagery from Frost gives many Twain admirers reason to be glad that he chose Kemble instead.

For in the end, Kemble is sufficiently mainstream for Houghton Mifflin in New York to select-and for Harris in Atlanta implicitly to reject-as acceptable for the divided audiences that they hoped would receive an illustrated Uncle Tom's Cabin, tailored for 1891 . Some readers would look to see the frequency of racial interactions that Kemble depicted between Eva and Uncle Tom; others would look to see the relative lack of interaction that he depicted among impoverished Southern whites, the forebears of the contested "Cracker" class of Georgians of 1891. Kemble could illustrate for those who wished to see "amalgamation" in the ancestry of Southern whites, and for those who refused to see "miscegenation" in the storyline of Uncle Tom's Cabin. He could supply audiences with conventional images of frolicking pickaninnies, which flattered a paternalistic Old South, and he could supply audiences with sensitive, individualized depictions of antebellum slaves, which credited the wisdom of abolitionism and emancipation. Unlike 


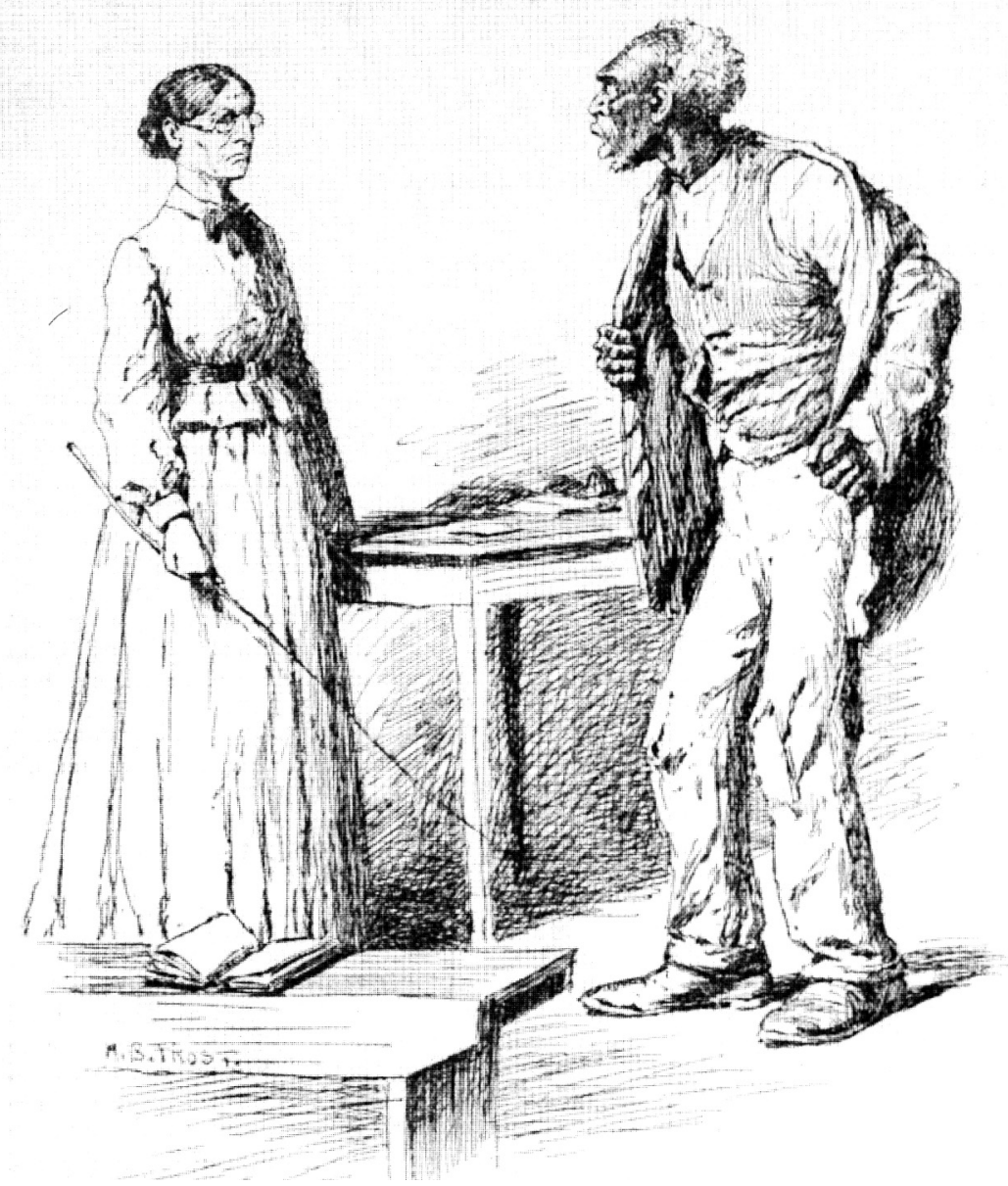

FIGURE 20. A. B. Frost's rendering of a "Schoolmarm" and an African American figure, to be contrasted with Kemble's renderings of Jim in Figures 21 and 22. From "Editor's Drawer," Harper's New Monthly Magazine Vol. ${ }_{5}$ No. 508 (September, 1892 ), page 642. Cleveland State University libraries, Cleveland, Ohio. 


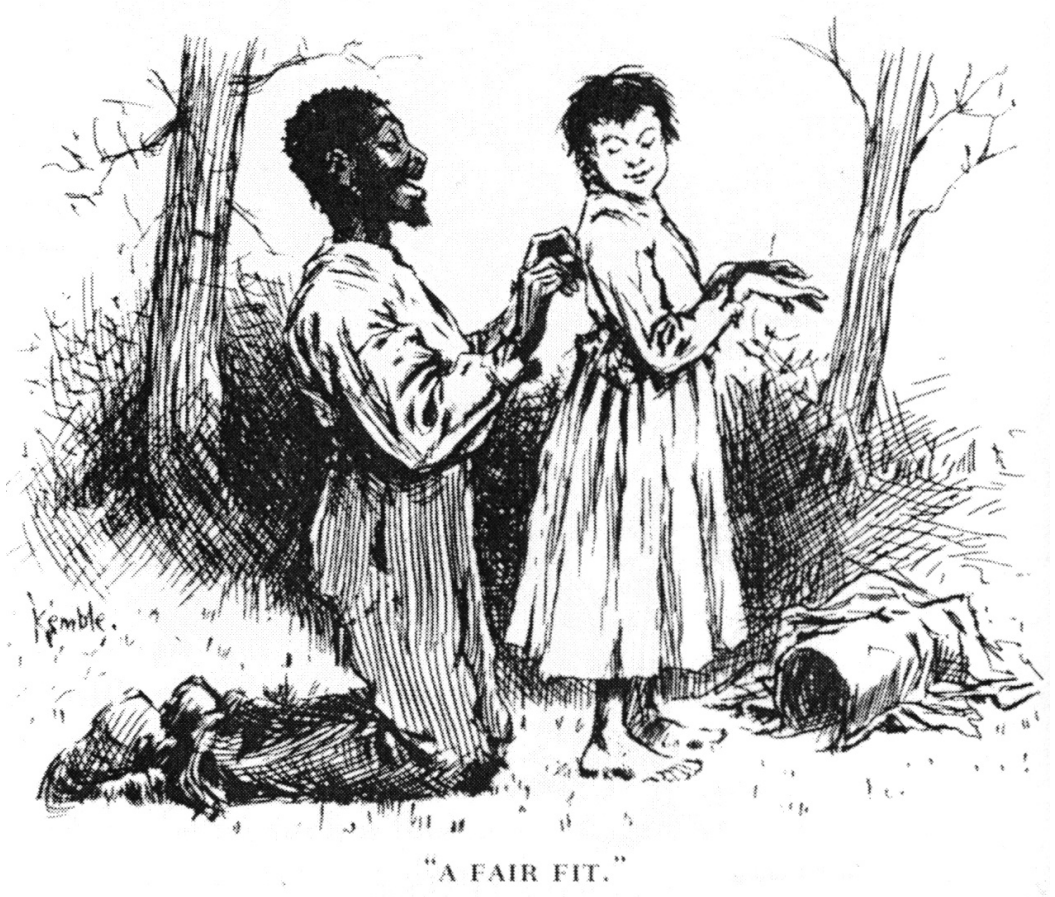

F I G U RE 21. Kemble's rendering of Huck and Jim. From Mark Twain, Adventures of Huckleberry Finn, A Norton Critical Edition. Ed. Thomas Cooley. New York: Norton, 1999. Cleveland State University libraries, Cleveland, Ohio. 


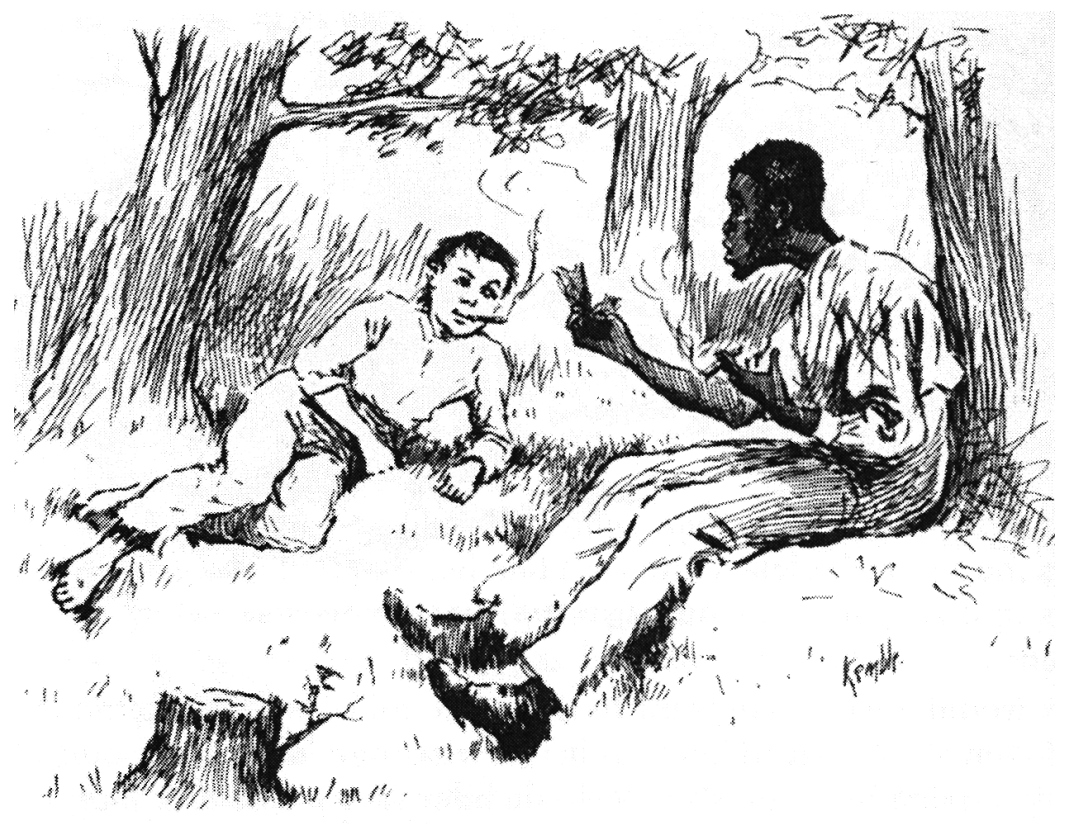

THE STORX OF "SOLLERMUN."

F I G U RE 22. Kemble's rendering of Huck and Jim. From Mark Twain, Adventures of Huckleberry Finn, A Norton Critical Edition. Ed. Thomas Cooley. New York: Norton, 1999. Cleveland State University libraries, Cleveland, Ohio. 
a marginalized, egregiously racist artist, Kemble so successfully mollified mainstream readers' sensitivities that his work adorned fictions marketed to both Northerners and Southerners. Unlike someone remembered solely as "Mark Twain's illustrator," he rendered visual imagery for the varied audiences of Irving, Stowe, Harris, Page, and Dunbar. Unlike a mere rogue anomaly in Twain studies, he aptly provided illustrations for Uncle Tom's Cabin's divided and demanding readership. The liberties that he took in pen and ink reflect the liberties that many late-nineteenth-century readers took in adapting the legacies of slavery, abolitionism, and socioeconomic and racial identities into a useable past for Gilded Age America.

\title{
Cleveland State University
}

\begin{abstract}
Adam Sonstegard, "Artistic Liberty and Slave Imagery: 'Mark Twain's Illustrator,' E. W. Kemble, Turns to Harriet Beecher Stowe” (pp. 499-542)

A comparison of Edward Windsor Kemble's illustrations for the first edition of Mark Twain's Adventures of Huckleberry Finn $\left(188_{4}-8_{5}\right)$ and for an 1891 edition of Harriet Beecher Stowe's Uncle Tom's Cabin (1852) shows that Kemble could render enslaved African Americans or impoverished European Americans as delineated individuals or as stereotypical figures, as he catered to audiences that had a stake in seeing these characters as unique personalities or as racialized "types." Marketing Twain's and Stowe's novels for mass audiences, Kemble mediated between literary authors who invest marginalized characters with distinct personalities and empowered, mainstream audiences who were less willing to accept individuality in minority figures. Kemble was not the egregiously racist exception for his time, but a reliable rule for the mainstream American publishing establishment; he typified Gilded Age readers who enjoyed the privileges of purchasing, reading, and illustrating literary representations of marginalized subjects-subjects who clearly did not enjoy such social privileges themselves. When Kemble takes artistic liberties in illustrating literary representations of slavery, then, he demonstrates graphically how Gilded Age readers were taking their own liberties reinterpreting these stories of slaves.
\end{abstract}

Keywords: Edward Windsor Kemble; Samuel Clemens; Harriet Beecher Stowe; graphic illustration; racial stereotype 